SIMULATION OF AQUIFER STORAGE RECOVERY OF EXCESS

DESALINATED SEAWATER, AL AIN AREA,

ABU DHABI EMIRATE

By C. B. Hutchinson

U. S. Geological Survey

Open-File Report 98-410

Prepared in cooperation with the

National Drilling Company

Emirate of Abu Dhabi

United Arab Emirates

Al Ain

September 1998 


\section{U.S. DEPARTMENT OF THE INTERIOR}

BRUCE BABBITT, Secretary

\section{U.S. GEOLOGICAL SURVEY}

Thomas J. Casadevall, Acting Director

The use of firm, trade, and brand names in this report is for identification purposes only and does not constitute endorsement by the U.S. Geological Survey.

For additional information write to:

Program Manager

NDC-USGS Ground-Water Research Program

P.O. Box 15287

Al Ain, United Arab Emirates

or call: $03 / 612544$

fax: 03/612606

email: gwrp@emirates.net.ae

Copies of this report may be purchased from:

U.S. Geological Survey

Information Services

Box 25286

Denver, Colorado 80225 


\section{CONTENTS}

Page

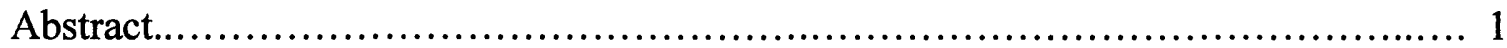

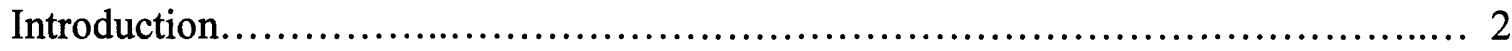

Purpose and scope........................................................... 4

Hydrogeologic framework................................................... 6

Model analysis of aquifer storage recovery................................. 8

Well model.......................................................... 9

Pond model............................................................. 14

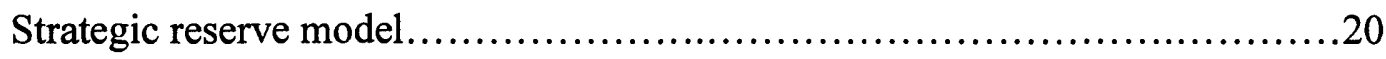

Conclusions..............................................................29

References..................................................................

Attachment 1: Applications of aquifer storage recovery in Arabian Gulf countries........32

Attachment 2: Definitions........................................................ 34

Abstract--Arabic translation by Fatima Al Nuaimi and Imad Tawfiq.....................35 


\section{ILLUSTRATIONS}

\section{Figure}

1. Map showing location of Abu Dhabi Emirate and Arabian Gulf countries

2. Map of Abu Dhabi Emirate, desalinization pipelines, and areas underlain by fresh ground water

3. Diagrams showing phases of aquifer storage and recovery of excess desalinated seawater.

4. Diagrammatic hydrogeologic section in eastern Abu Dhabi Emirate............... 7

5. Map showing water table and directions of ground-water flow, 1995.......... 7

6. Diagrams showing aquifer storage recovery well model grid and boundary conditions.

7. Graphs showing simulated head and dissolved-solids concentration in observation wells for multiple aquifer storage recovery cycles of injection and pumping in the well model.

8. Diagrams showing simulated heads, dissolved-solids concentrations, and flow pathlines after 2,000 days and eight aquifer storage recovery cycles in the well model.

9. Diagrams showing visualization of the water table and dissolvedsolids concentrations in the surficial aquifer system at the end of eight cycles of simulated storage and recovery of desalinated seawater in the well model.

10. Diagrams showing aquifer storage recovery pond model grid and boundary conditions.

11. Graphs showing simulated head and dissolved-solids concentration in observation wells for multiple aquifer storage recovery cycles of pond infiltration and pumping one well in the pond model...

12. Diagrams showing simulated heads, dissolved-solids concentrations, and flow pathlines after 1,825 days and five aquifer storage recovery cycles in the pond model

13. Diagrams showing visualization of the water table and dissolvedsolids concentrations in the surficial aquifer system at the end of five cycles of simulated storage and recovery of desalinated seawater in the pond model....

14. Diagrams showing the aquifer storage recovery strategic reserve model grid, well distribution, and boundary conditions.

15. Graphs showing simulated head and dissolved-solids concentration for one aquifer storage recovery cycle of pond infiltration and pumping 15 wells in the strategic reserve model. 


\section{ILLUSTRATIONS-Continued}

Figure

$\underline{\text { Page }}$

16. Diagrams showing simulated ground-water velocity after 1,095 days of recharging 1,000 cubic meters per day in the strategic reserve model

17. Diagrams showing simulated ground-water velocity after 1,095 days of recharging 1,000 cubic meters per day and 10 days of pumping 15,000 cubic meters per day in the strategic reserve model.

18. Diagrams showing simulated heads, dissolved-solids concentrations, and flow pathlines after 1,095 days of recharging 1,000 cubic meters per day in the aquifer storage recovery strategic reserve model

19. Diagrams showing simulated heads, dissolved-solids concentrations, and flow pathlines after 1,095 days of recharging 1,000 cubic meters per day and 10 days of pumping 15,000 cubic meters per day in the aquifer storage recovery strategic reserve model.

20. Diagrams showing visualization of the water table and dissolvedsolids concentrations in the surficial aquifer system at the end of one cycle of simulated storage and recovery of desalinated seawater in the strategic reserve model.

\section{TABLES}

Table

$\underline{\text { Page }}$

1 Hydrogeologic framework of eastern Abu Dhabi Emirate 


\section{CONVERSION FACTORS}

\section{Multiply}

centimeter $(\mathrm{cm})$

meter (m)

kilometer $(\mathrm{km})$

square meter $\left(\mathrm{m}^{2}\right)$

hectare (ha)

square kilometer $\left(\mathrm{km}^{2}\right)$

cubic meter $\left(\mathrm{m}^{3}\right)$

cubic meter $\left(\mathrm{m}^{3}\right)$

centimeter per day $(\mathrm{cm} / \mathrm{d})$

meter per day $(\mathrm{m} / \mathrm{d})$

square meter per day $\left(\mathrm{m}^{2} / \mathrm{d}\right)$ cubic meter per day $\left(\mathrm{m}^{3} / \mathrm{d}\right)$ cubic meter per day $\left(\mathrm{m}^{3} / \mathrm{d}\right)$ cubic meter per day $\left(\mathrm{m}^{3} / \mathrm{d}\right)$ cubic meter per day $\left(\mathrm{m}^{3} / \mathrm{d}\right)$

degree Celsius $\left({ }^{\circ} \mathrm{C}\right)$

milligram per liter $(\mathrm{mg} / \mathrm{L})$
By

\section{Length}

2.54

3.281

0.6214

\section{Area}

10.764

2.47

0.3861

Volume

220

264

\section{Flow}

2.54

3.281

10.764

0.153

0.183

220

264

Imperial gallon (gal)

United States gallon (gal)

$$
\begin{array}{r}
\text { square foot }\left(\mathrm{ft}^{2}\right) \\
\text { acre }(\mathrm{ac}) \\
\text { square mile }\left(\mathrm{mi}^{2}\right)
\end{array}
$$

inch (in)

foot (ft)

mile (mi)

\section{Temperature}

(1)

degree Fahrenheit $\left({ }^{\circ} \mathrm{F}\right)$

\section{Concentration}

1

parts per million (ppm)

(1) ${ }^{\circ} \mathrm{F}=1.8 \times\left({ }^{\circ} \mathrm{C}\right)+32$.

Sea level: $\quad$ In this report, "sea level" refers to the Nahrwan Datum of 1967. 


\title{
SIMULATION OF AQUIFER STORAGE RECOVERYOF EXCESS DESALINATED SEAWATER, AL AIN AREA, ABU DHABI EMIRATE
}

\author{
By C.B. Hutchinson
}

\begin{abstract}
The surficial aquifer system in $\mathrm{Al}$ Ain area is being depleted of vital fresh groundwater. Desalinization plants at Umm Al Nar and Taweelah in coastal Abu Dhabi Emirate produced 700,000 cubic meters per day in 1997 and pipelines carried supplemental water to $\mathrm{Al}$ Ain. It may be feasible to store excess desalinated seawater underground in the surficial aquifer system in $\mathrm{Al}$ Ain area for future recovery during time of need. This technique, known as "aquifer storage recovery," or ASR, has been tested in Kuwait and Qatar.

The computer models, Visual Modflow and Visual Groundwater, were used to simulate and visualize three hypothetical scenarios for aquifer storage recovery of freshwater. The models were based on estimates for regional aquifer conditions of head, hydraulic conductivity, specific yield, and dissolved-solids concentration. The models were used to demonstrate the practicality of computer analysis before conducting field tests.

The first simulation is a well model, whereby 1,000 cubic meters per day are injected for 200 consecutive days and then recovered at a rate of 1,000 cubic meters per day for 50 days on an 8-ASR-cycle schedule lasting 2,000 days. The simulated average dissolved-solids concentration of the recovered water is about 500 milligrams per liter. The remaining simulated plume of freshwater with a dissolved-solids concentration less than 1,500 milligrams per liter occupies an area of 100,000 square meters and the volume added to aquifer storage is $1,200,000$ cubic meters.

The second simulation is a pond model, whereby 1,000 cubic meters per day seeps through the bottom of an infiltration pond for 245 consecutive days and then a downgradient recovery well is pumped at 1,000 cubic meters per day for 120 days for a cyclic schedule lasting 1,825 days, or 5 years. This is realistic from the standpoint that excess desalinated water may be available for storage during off-peak demand periods and recovered during peak demand periods. The dissolved-solids concentration of the recovered water decreased with successive ASR cycles and generally was less than 1,000 milligrams per liter. The simulated plume of freshwater after 1,825 days, or five ASR cycles, occupied an area of 88,000-square meters and a volume of 660,000 cubic meters.
\end{abstract}

The third simulation is a strategic reserve model, whereby 1,000 cubic meters per day are allowed to seep through an infiltration pond for 3 years and subsequent recovery is by 15 wells pumping a total of 15,000 cubic meters per day for 10 days. The need for a strategic reserve is evident from past water shortages that occurred when desalinization plants were shut down due to oil spills in the Arabian Gulf. The simulated dissolvedsolids concentration of the blended water recovered from the 15 wells averaged about 1,100 milligrams per liter. The remaining plume of freshwater covered an area of 105,000 square meters and occupied a volume of 795,000 cubic meters.

Conclusions drawn from results of the preliminary models based on average hydrologic conditions indicate that aquifer storage recovery is a viable alternative for augmenting the depleted aquifer near Al Ain and for creating a reservoir of freshwater for emergency withdrawal. The models are a cost-effective means for analysis of the aquifer's potential for accepting storage and yielding water and are ideal for use in the design of a storage recovery facility, including size of the area, well design, monitoring locations, and storage recovery rates and schedules. Although only three examples of aquifer storage recovery were analyzed, they have demonstrated possible situations that would have cost millions of dirhams to implement. 


\section{INTRODUCTION}

The Emirate of Abu Dhabi occupies an area of 59,200 square kilometers on the Arabian Peninsula. The Emirate is bounded by the Sultanate of Oman on the east, the Kingdom of Saudi Arabia on the south and west, and the Arabian Gulf on the north (fig. 1). The Emirate has a 350-kilometer-long coastline that is dotted with seawater desalinization/power plants that produce electricity from steam generators and freshwater from condensation of the steam. Because electricity and water demand are not always proportional, excess desalinated water is sometimes wasted as discharge directly to the sea or the efficiency of the desalinization system is reduced to regulate water production.

Desalinization plants at Umm Al Nar and Taweelah in coastal Abu Dhabi Emirate produced about 700,000 cubic meters per day in 1997 (Abu Dhabi Water and Electricity Authority, 1997). The plants have a total capacity of just under 900,000 cubic meters per day. Total export capacity from the desalinization plants to the city of $\mathrm{Al}$ Ain reached about 100,000 cubic meters per day in 1997 when a new pipeline was completed from the

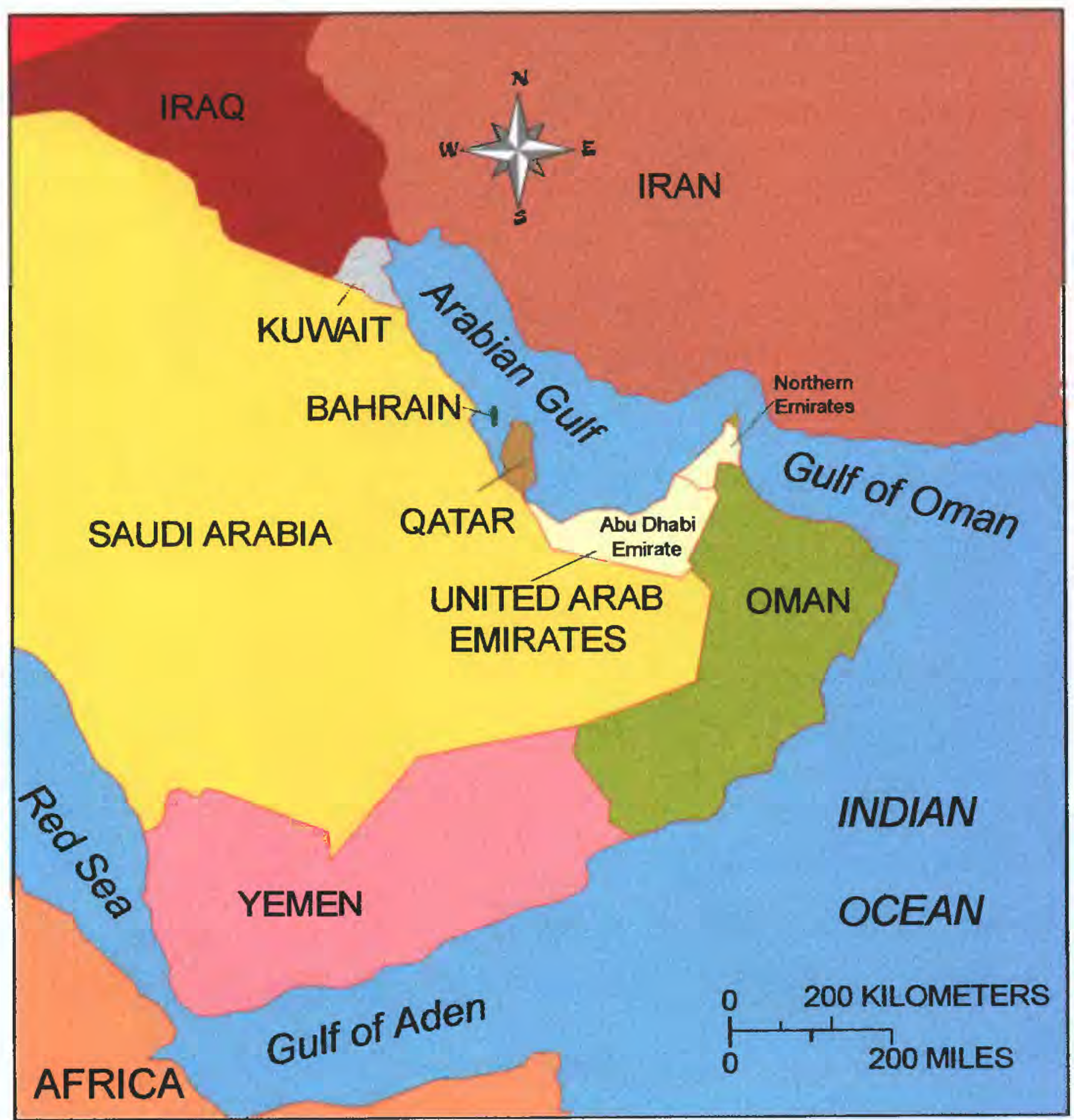

Figure 1. Location of Abu Dhabi Emirate and Arabian Gulf countries. 
Taweelah 'B' plant located on the Arabian Gulf coast about 50 kilometers northeast of Abu Dhabi (fig. 2). Because the desalinization pipeline is built to meet projected future needs for the year 2010, there is capacity to deliver excess water to Al Ain. The prime period for delivering this excess water is probably the winter months when use of desalinated water for garden and ornamental plant irrigation is minimal. During summer months when air temperature rises above 110 degrees Fahrenheit ( 43 degrees Celsius), irrigation requirements are high, and the city of $\mathrm{Al}$ Ain frequently has water shortages.

Water levels in the surficial aquifer system in $\mathrm{Al}$ Ain area have been in decline since 1985 due to increasing annual pumpage for municipal and agricultural supplies. The National Drilling Company (NDC) of Abu Dhabi Emirate undertook a study in 1998 to assess the feasibility of augmenting and revitalizing the critical ground-water resources of $\mathrm{Al}$ Ain area. The U.S. Geological Survey, under terms of a cooperative agreement with NDC, provided technical assistance on application of ground-water modeling techniques to assist the study. One aspect of this study was to assess the potential for subsurface storage and recovery of excess desalinated water.

Aquifer storage recovery (ASR) was defined by Pyne (1994) as "the storage of water in a suitable aquifer through a well during times when water is available, and recovery of the water from the same well during times when it is needed." This technique is being used in the United States, Canada, Israel, England, Netherlands, and Australia to ensure continuity of public water supplies during periods of drought. Kuwait and Qatar are Arabian Gulf countries that have experimented with ASR (Abdulrazzak, 1997). Because the climate and water conditions of these two neighboring countries are similar to those of Abu Dhabi Emirate, case studies of ASR are presented in Attachment 1.

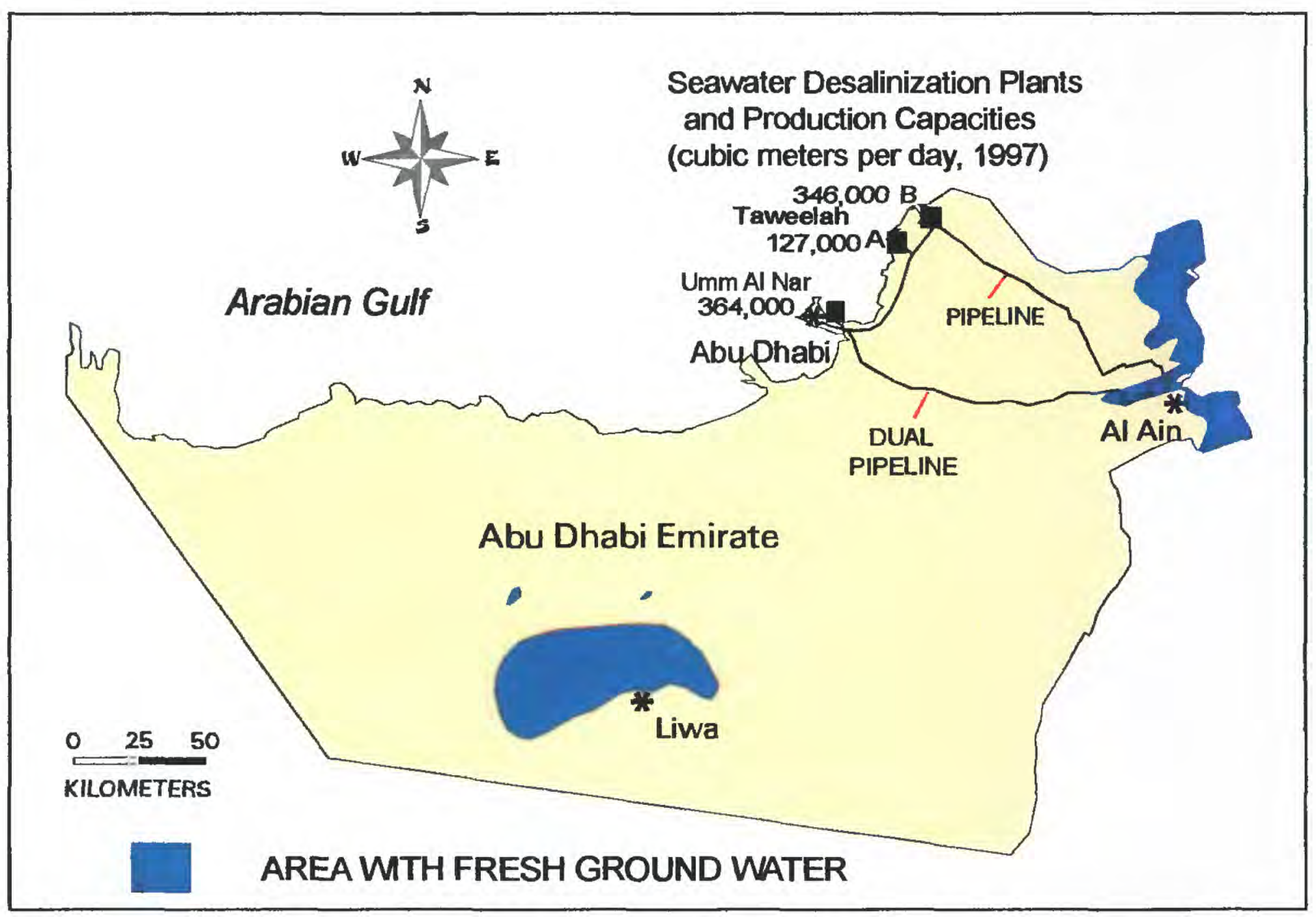

Figure 2. Abu Dhabi Emirate, desalinization pipelines, and areas underlain by fresh ground water. 
The application of ASR in Abu Dhabi Emirate is a potential solution to a problem facing water managers in the Emirate. Desalinization plants are threatened by contamination from environmental disasters or other crises. For example in January 1998, the desalinization plants at Sharjah an Ajman in the Northern Emirates were shut down when an oil barge spilled nearly 5,000 tons of fuel oil near the Arabian Gulf port cities (Hassan, 1998). Because backup facilities were insufficient to meet water demand, many homes and businesses experienced a water shortage. It may have been feasible to extract water from an aquifer to satisfy critical needs if a reserve had been established through implementation of an ASR program.

About 1,600 square kilometers near Al Ain are underlain by fresh ground water (fig. 2) containing a total dissolved-solids concentration of less than $1,500 \mathrm{mg} / \mathrm{L}$ (Tamayo, 1997). Until 1997, this water was the main source of supply for the city of $\mathrm{Al}$ Ain. With completion of the Taweelah ' $B$ ' desalinization pipeline, municipal stresses on the fresh ground-water supply were alleviated, however, stresses from agricultural pumpage continue to grow. This area is favorable for field testing ASR because of the locations of the desalinization pipelines. Desalinated water could be siphoned from the pipeline, stored in the surficial aquifer system by injection or infiltration, recovered in time of need, and sent through the pipeline to Abu Dhabi or to Al Ain. An example of this idea for an ASR system is illustrated in figure 3. The declining resources would be partially restored, and the tests would not be complicated by large salinity and density contrasts between the imported water and the native ground water.

Computer models of ground-water flow and solute transport can be used to assess the feasibility of ASR prior to conducting expensive field tests. The models can be used to simulate the buildup of freshwater at a storage site through an injection well or an infiltration pond, the movement and concentration of the water over time, and the efficiency of different recovery schemes. Models normally are used to understand the flow system in a broad sense because they are constrained by grid size and availability of data. If the limitations are understood, models can be useful tools for ground-water management.

\section{PURPOSE AND SCOPE}

The purpose of this report is to demonstrate the results of ASR computer-model test simulations undertaken by the NDC Ground-Water Research Program in early 1998. The study is one aspect of a 2-year investigation into the feasibility for recharging the ground-water system in $\mathrm{Al}$ Ain area.

The computer programs, MODFLOW (McDonald and Harbaugh, 1988) and MT3D (Zheng, 1990), were used to simulate the surficial aquifer system and assess the potential for ASR. Versions of the software used to compute and visualize model results are titled "Visual Modflow" (Guiguer and Franz, 1996) and "Visual Groundwater" (Waterloo Hydrogeologic, Inc., 1996).

Visual Modflow (VM) was used to simulate hypothetical cycles of storage, or recharge, either by injection through a well or infiltration beneath a pond, and cycles of recovery by pumping the injection well or a well near the pond. Visual Groundwater (VG) was used to illustrate and animate the VM results. This visualization included observing the development of the stored plume of freshwater over time, its movement downgradient with the regional flow-field, and the effects of extracting the water by a strategically placed pumped well(s). The models, hereafter termed the "model package," were also used to demonstrate the effectiveness of injection-recovery schedules and recovery well design and placement. 


\section{A. STORAGE PHASE}

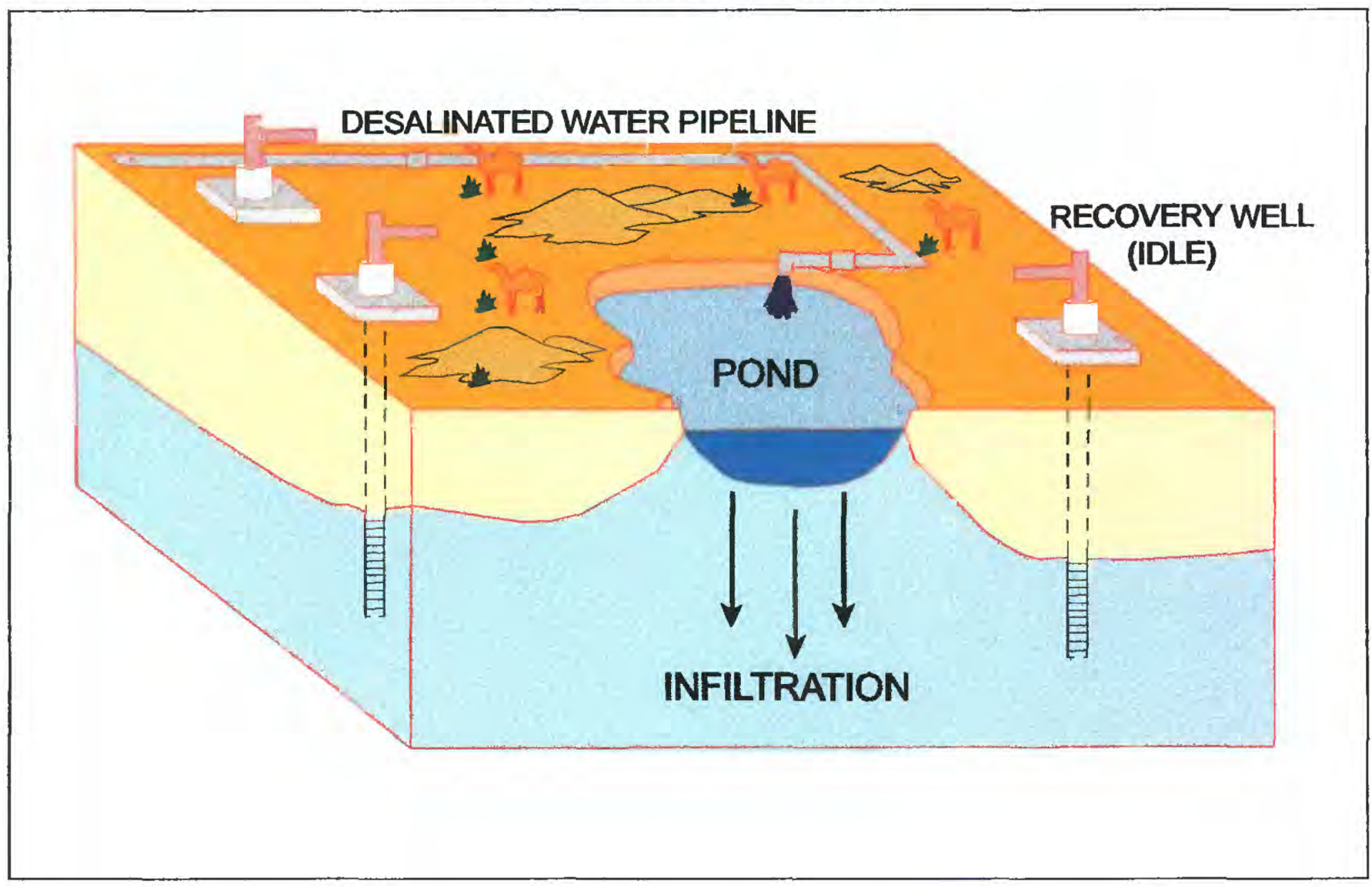

B. RECOVERY PHASE

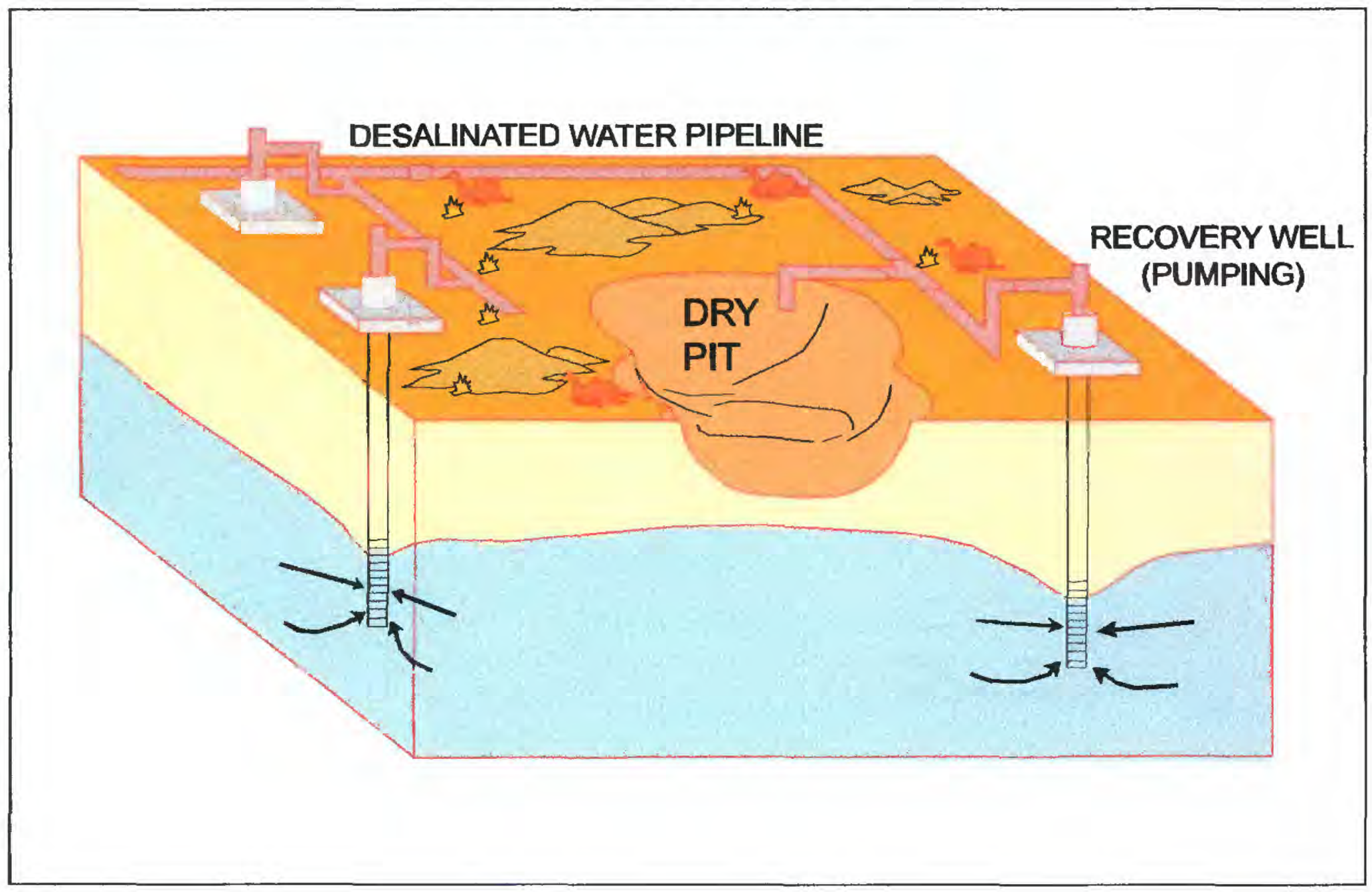

Figure 3. Phases of aquifer storage (A) and recovery (B) of excess desalinated seawater. 


\section{HYDROGEOLOGIC FRAMEWORK}

The hydrogeologic framework of eastern Abu Dhabi Emirate has been described in unpublished reports on file with the National Drilling Company. The hydrogeologic framework derived from these reports is summarized in table 1. The surficial aquifer system is unconfined and consists of highly productive Quaternary alluvium eroded from mountains in northern Oman and underlain in some areas by less productive altered (weathered) Tertiary deposits of continental and marine origin (fig. 4). A karstic limestone unit of Cretaceous age occurs as upthrust pinnacles (jabals and qarns) that are exposed at land surface and are hydraulically connected to the surrounding alluvial deposits. Transmissivity is highly variable with median values of $730 \mathrm{~m}^{2} / \mathrm{d}$ for the combined Quaternary alluvium and altered Tertiary deposits, and $475 \mathrm{~m}^{2} / \mathrm{d}$ for local occurrences of the karstic limestone. The use of 'median' values for transmissivity is questionable because many wells are dry or nearly so. Reported transmissivity values are generally based on calculable pump tests, therefore, results of averaging are biased toward the high range. In areas where the alluvium overlies altered Tertiary deposits, the base of the surficial aquifer system can not be clearly distinguished on the basis of drill cuttings. The base was defined to be within the transition zone between altered and unaltered Tertiary deposits on the basis of hydraulic conductivity calculations made using borehole geophysical logs.

The water table in the surficial aquifer system generally slopes westward from a high between 260 and 360 meters above sea level at the Sultanate of Oman-Abu Dhabi Emirate boundary north of $\mathrm{Al} \mathrm{Ain} \mathrm{(fig.} \mathrm{5).} \mathrm{The} \mathrm{average} \mathrm{westward} \mathrm{gradient,} \mathrm{based} \mathrm{on} 100$ meters of head change over 25 kilometers of distance is 0.004 . The average saturated thickness of the surficial aquifer system is about 75 meters and the overlying unsaturated zone is between 25 and 50 meters thick. Three areas north, west, and southeast of $\mathrm{Al}$ Ain had severe water-table declines of more than 10 meters between 1990 and 1995 .

Table 1. Hydrogeologic framework of eastern Abu Dhabi Emirate. (National Drilling Company, written communication, 1998)

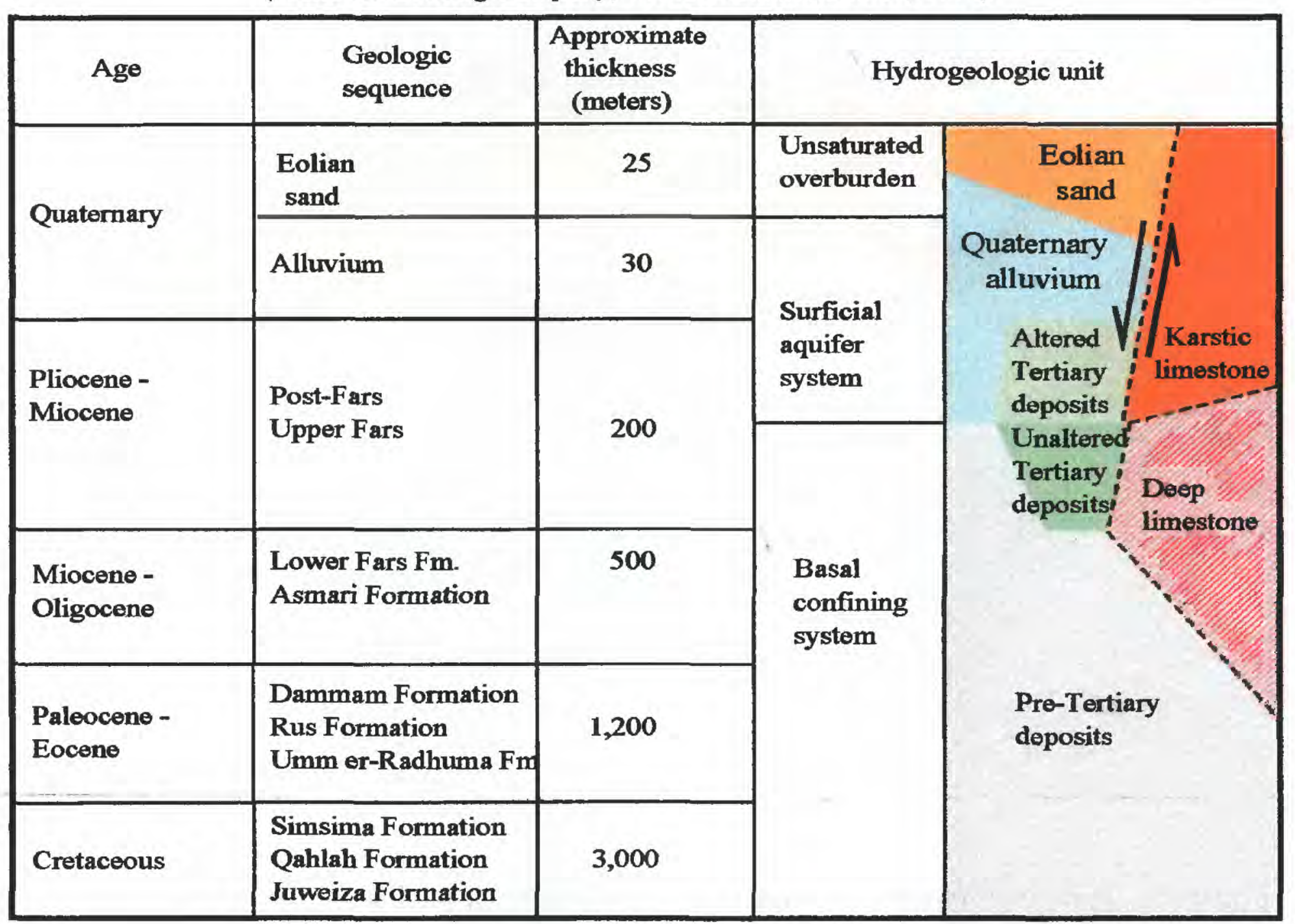




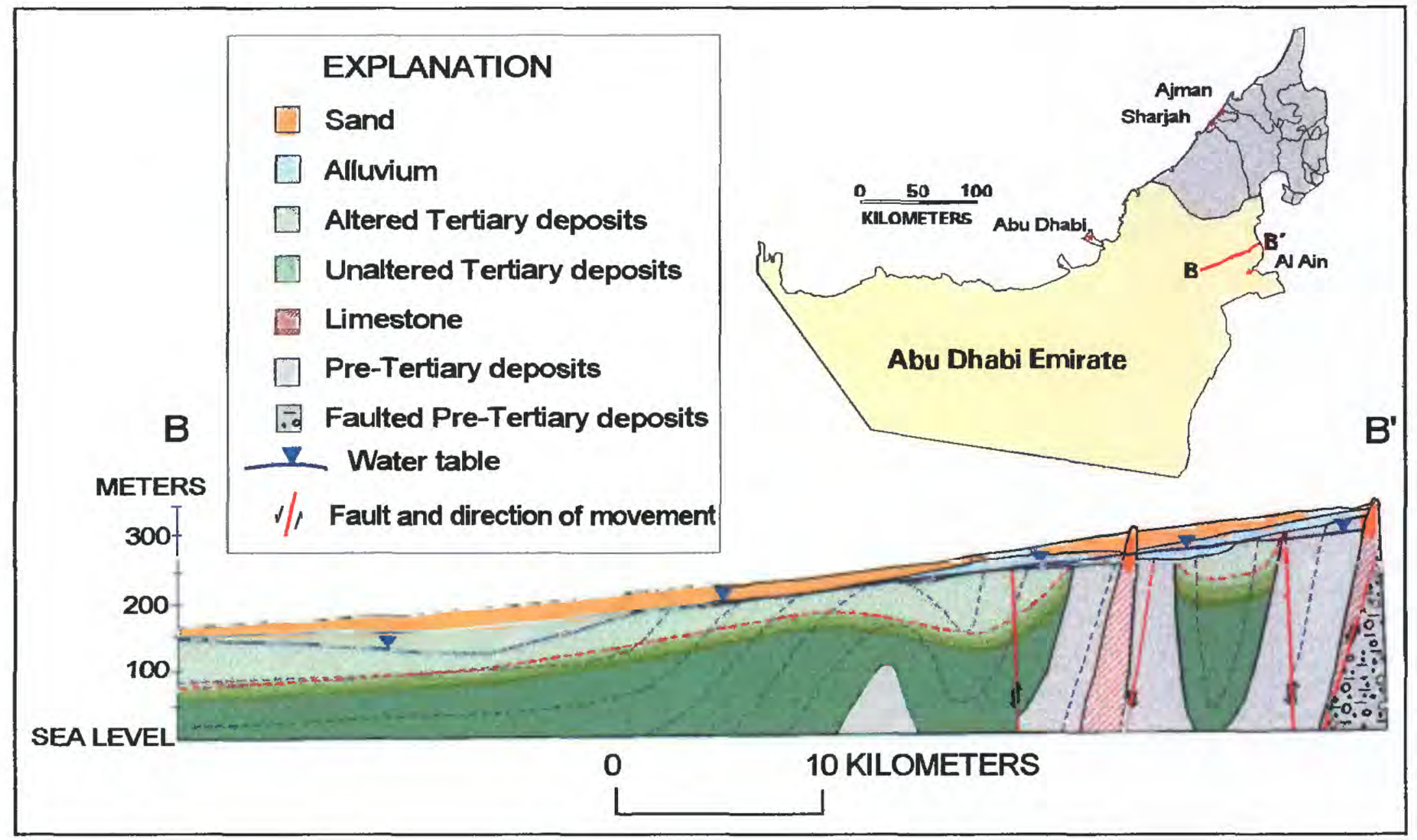

Figure 4. Diagrammatic hydrogeologic section in eastern Abu Dhabi Emirate.

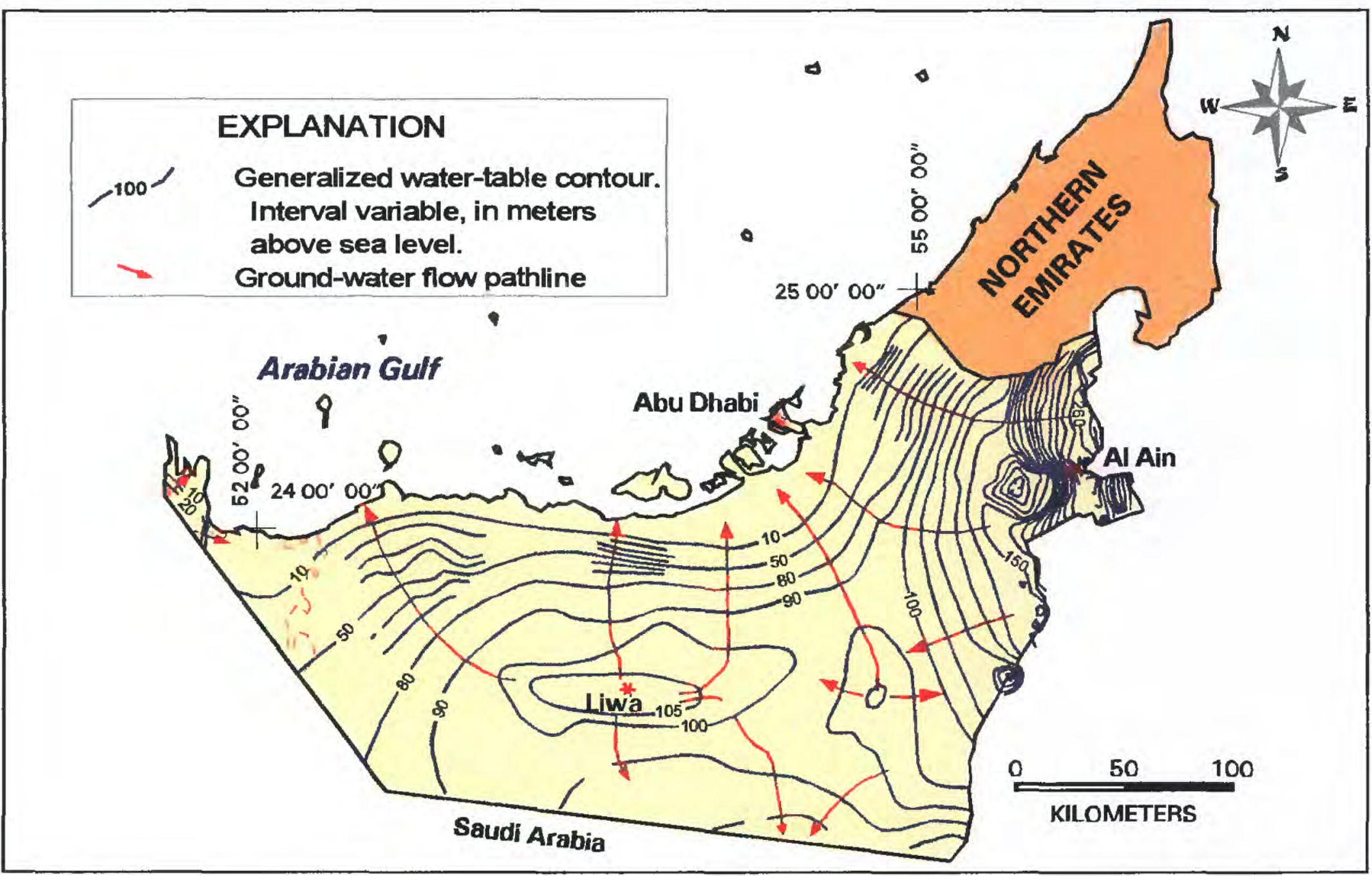

Figure 5. Water-table and directions of ground-water flow, 1995. 


\section{MODEL ANALYSIS OF AQUIFER STORAGE RECOVERY}

Three ASR scenarios were simulated: (1) using a well for recharge by injection and recovery by pumping; (2) using a surface pond for recharge by infiltration and a nearby well for recovery on an annual cycle; and (3) using a surface pond for recharge of a strategic reserve for emergency withdrawal. The models were based on average hydrogeologic conditions described in unpublished administrative reports on file with NDC and estimates for model parameters consisting of:

1. aquifer block, $1.02-\mathrm{km}$ long $\times 1.02-\mathrm{km}$ wide $\times 80-\mathrm{m}$ thick, surface datum, $0 \mathrm{~m}$;

2. layer depths below datum, $60,70,80,90,100,110,120,130,150 \mathrm{~m}$;

3. horizontal hydraulic conductivity, $8 \mathrm{~m} / \mathrm{d}$;

4. vertical hydraulic conductivity, $2 \mathrm{~m} / \mathrm{d}$;

5. specific storage, 0.001 ;

6. specific yield, 15 percent;

7. porosity, 0.2 ;

8. depth to water table (top of aquifer) below datum, $48 \mathrm{~m}$ to $52 \mathrm{~m}$;

9. water-table gradient 0.004 , or $4 \mathrm{~m} / \mathrm{km}$;

10. depth to basal confining layer below datum, $130 \mathrm{~m}$;

11. thickness of confining layer, $20 \mathrm{~m}$;

12. horizontal hydraulic conductivity of confining layer, $0.001 \mathrm{~m} / \mathrm{d}$;

13. vertical hydraulic conductivity of confining layer, $0.0001 \mathrm{~m} / \mathrm{d}$.

14. ground surface depth below datum, 0 to $4 \mathrm{~m}$;

15. TDS concentration of native ground water, $2,000 \mathrm{mg} / \mathrm{L}$;

16. TDS concentration of desalinated recharge water, $200 \mathrm{mg} / \mathrm{L}$;

17. longitudinal dispersivity, $20 \mathrm{~m}$;

18. horizontal transverse dispersivity, $10 \mathrm{~m}$;

19. vertical transverse dispersivity, $2 \mathrm{~m}$;

The model represents a porous block that is subdivided using a grid of 51 rows, 51 columns, and 9 layers into a matrix of 23,409 grid blocks, or 'cells', each 20 meters square and between 10 and 60 meters thick. Each cell was assigned values for vertical and horizontal hydraulic conductivity, specific storage, specific yield, porosity, TDS concentration, and dispersivity. Constant-head boundaries of 48 and 52 meters below the datum were assigned to columns 1 and 51 to simulate a water-table gradient; a constant concentration boundary was assigned to the upgradient column to simulate native formation water entering the model to replace that which flows out of the model in the downgradient column. Rows 1 and 51 represent no-flow boundaries that prevent lateral inflow and outflow. The confining layer at a depth of 130 meters represents the unaltered Tertiary deposits, which restrict vertical movement of ground water. The surficial aquifer system, therefore, lies between the water table and the confining unit and is represented by homogenous deposits with a saturated thickness between 78 and 82 meters. The unsaturated zone above the water table is 48 meters thick and slopes parallel to the land surface.

Recharge to the system was simulated as injection through a well and as infiltration through the bottom of a pond. Recharge-water concentration was simulated as a point source with a TDS concentration of 200 milligrams per liter. This representation of desalinated water was distributed evenly along the injection well screen or pond bottom. Storage recovery was simulated as cyclic stress periods, commencing with the storage phase followed by recovery. Between 1 and 8 ASR cycles over as many as 2,000 days were simulated to observe flushing of the native ground water and buildup of a plume of desalinated water. Each cycle consisted of a storage phase followed by a recovery phase. 
The model package produced maps of the head and TDS concentration distributions at the end of each stress period, graphs of heads and TDS concentrations in strategically placed observation wells, and ground-water flow pathlines and velocities. The model was also used to evaluate the efficiency of the simulated recovery by estimating the average TDS concentration of the recovered water and the volume of freshwater remaining in the aquifer. The maximum run time on a personal computer was about 10 minutes to compute head, flux, and concentration in each cell for the 16 stress periods in the 8cycle ASR simulation, accounting for 1.1 million pieces of information.

The model package also produced three-dimensional images of the ground-water system in colors and to animate the movement of the desalinated-water plume over time. These representations provided insight as to where potential monitoring wells could be located for efficiency of recovery.

\section{Well Model}

The well model consisted of simulating a (ASR) well 120 meters upgradient of the middle of the aquifer block, screened between 60 and 130 meters below land surface (figs. 6-9). The simulated ASR consisted of injecting $200-\mathrm{mg} / \mathrm{L}$ water at a rate of 1,000 $\mathrm{m}^{3} / \mathrm{d}(183 \mathrm{gal} / \mathrm{min})$ for 200 days and pumping at a rate of $1,000 \mathrm{~m}^{3} / \mathrm{d}$ for 50 days on a cyclic schedule lasting 2,000 days, or 5.5 years. The injection-recovery ratio of 4:1 indicates that much more water was stored than recovered. This ASR scenario tests the feasibility of augmenting the dwindling ground-water resources and withdrawing small quantities of recharged water in time of need.

Simulated results for the well model of ASR are shown in figures 7 and 8 . The upper graph in figure 7 shows water-levels in two observation wells 160 meters upgradient (WL-1) and 200 meters downgradient (WL-2) of the ASR well. The lower graph shows TDS concentrations in the middle of the aquifer (about 95 meters below land surface) in the ASR well and four quality-of-water monitoring wells located 100 meters upgradient (QW-1) and 100, 300 and 500 meters downgradient (QW-2, QW-3, and QW-4) of the ASR well. The graphs show the cyclic nature of the storage and recovery by halfmeter fluctuations in water levels and by stepped TDS concentration levels in the nearest QW wells. The QW wells also indicate a progressive decrease in TDS concentration as $200 \mathrm{mg} / \mathrm{L}$ water is added to the system and moves downgradient toward well QW-4. The TDS concentration of the recovered water from the ASR well increases as the water is withdrawn. The increase is from about 200 to $1,000 \mathrm{mg} / \mathrm{L}$ on the first cycle and from about 200 to $700 \mathrm{mg} / \mathrm{L}$ on the eighth cycle. The average TDS concentration of the recovered water is about $500 \mathrm{mg} / \mathrm{L}$.

The simulated plume of freshwater after 2,000 days ( 8 cycles) of ASR is shown in figure 8. The thickness of the plume is fairly constant as shown in the cross-sectional view. This indicates that the injected water simply displaced the native ground water. The interface between the injected freshwater and the native brackish water is relatively sharp upgradient of the ASR well because inflow of $2,000 \mathrm{mg} / \mathrm{L}$ water from the boundary pushed the interface toward the ASR well. Downgradient, the interface is wide due to advection in the downgradient direction, mechanical dispersion, and back and forth mixing during ASR cycles. Ground-water pathlines indicate that the leading edge of the freshwater moved a little more than 400 meters downgradient from the ASR well. Pathlines from the upgradient boundary indicate that native ground water moved about 300 meters. Spacing between arrowheads on the pathlines indicate that the water would move downgradient at a fairly uniform rate. 
A. PLAN VIEW

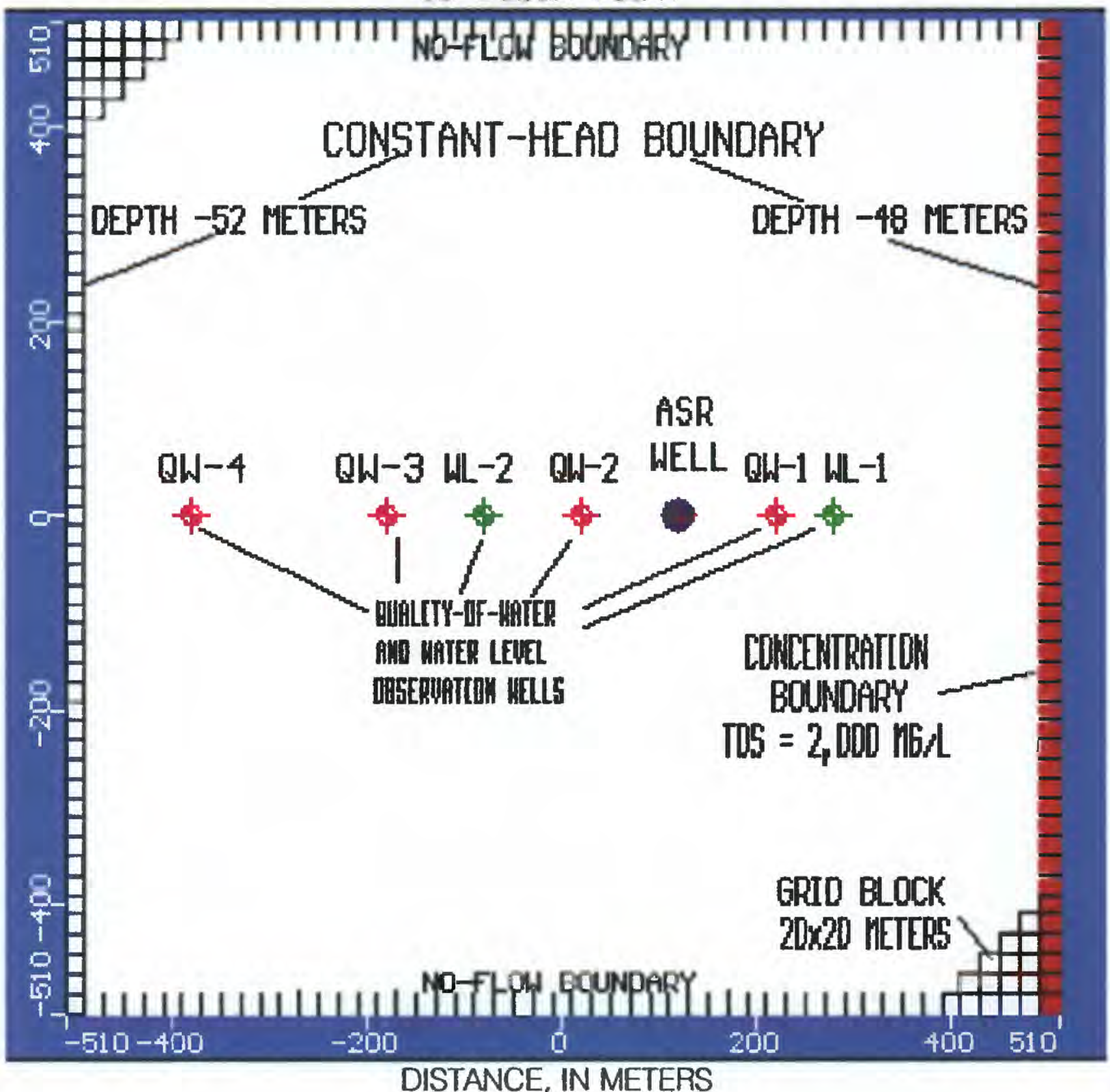

B. CROSS SECTION, ROW 0

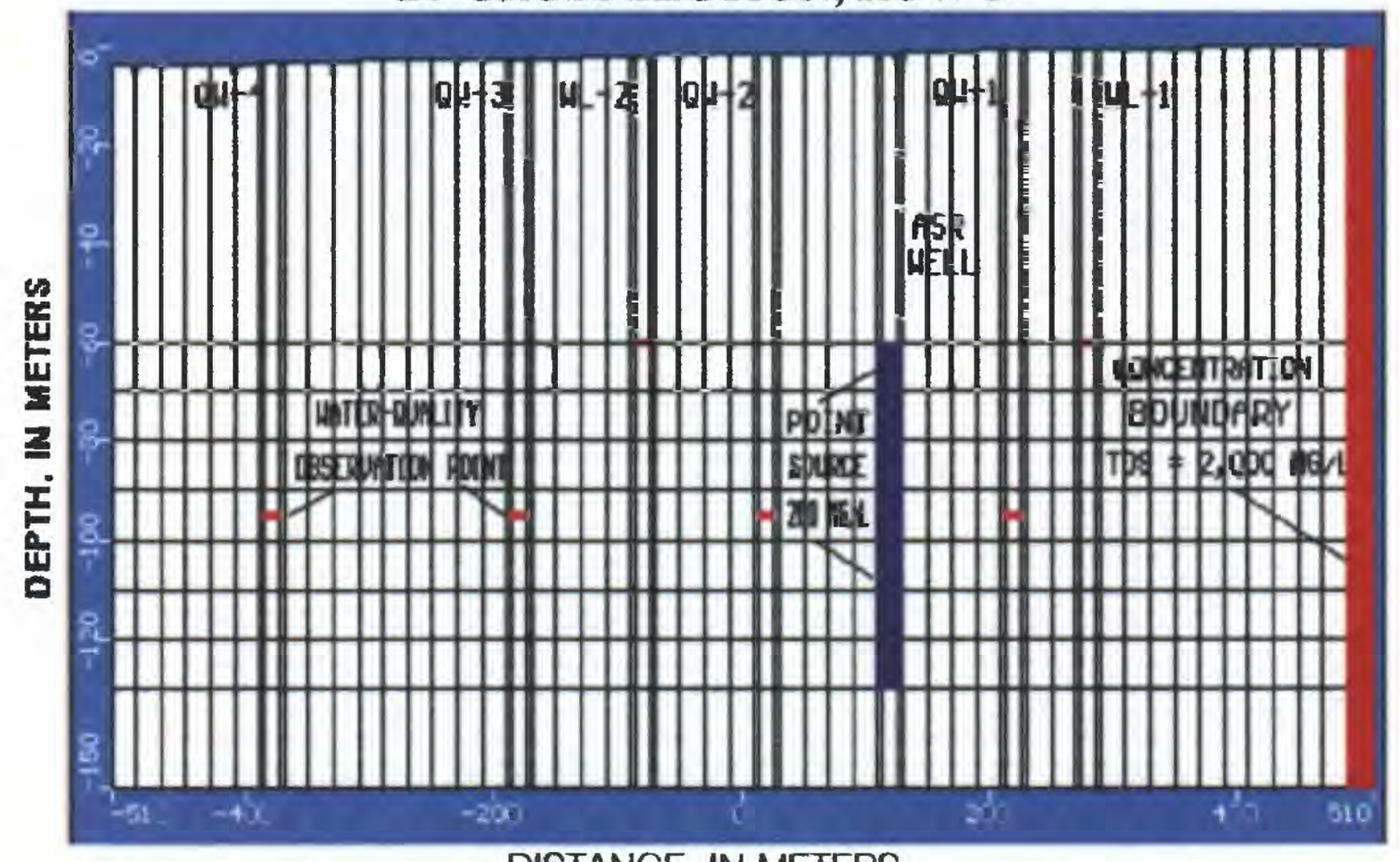

DISTANCE, IN METERS

Figure 6. Aquifer storage recovery well model grid and boundary conditions. 

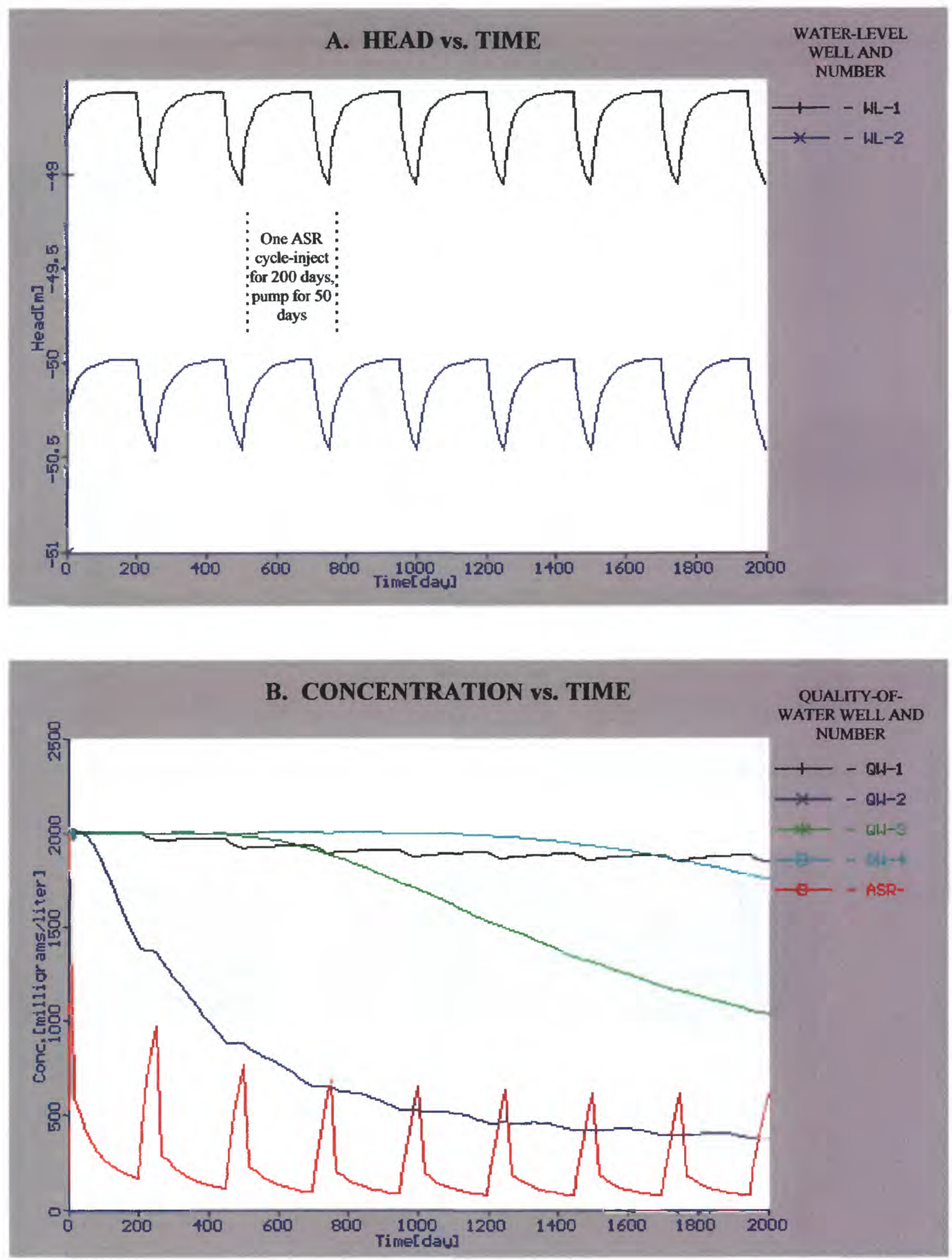

Figure 7. Simulated head (A) and dissolved-solids concentration (B) in observation wells for multiple aquifer storage recovery cycles of injection and pumping in the well model. 
A. PLAN VIEW, LAYER 5, DEPTH 95 METERS

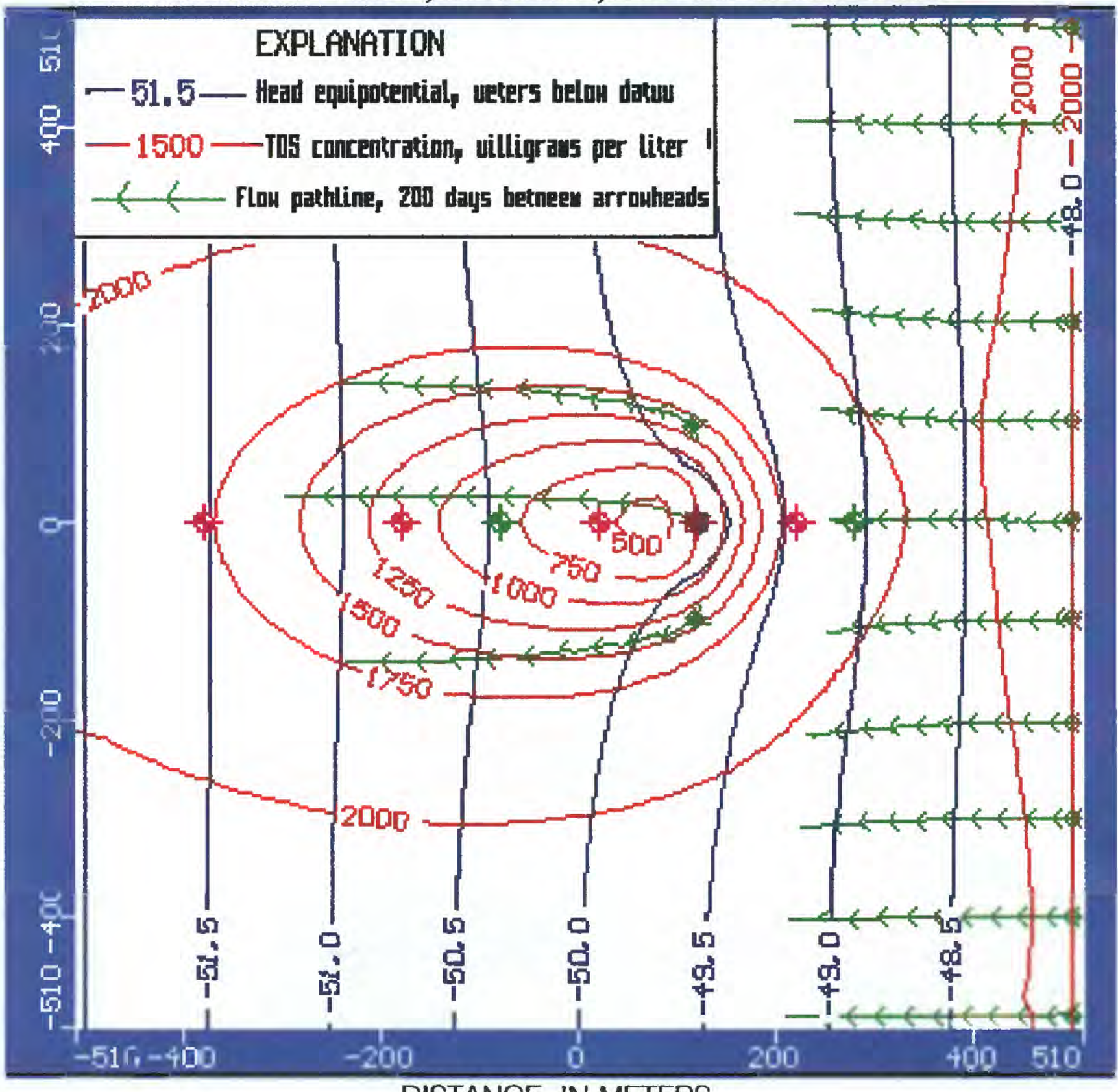

DISTANCE, IN METERS

\section{B. CROSS SECTION, ROW 0}

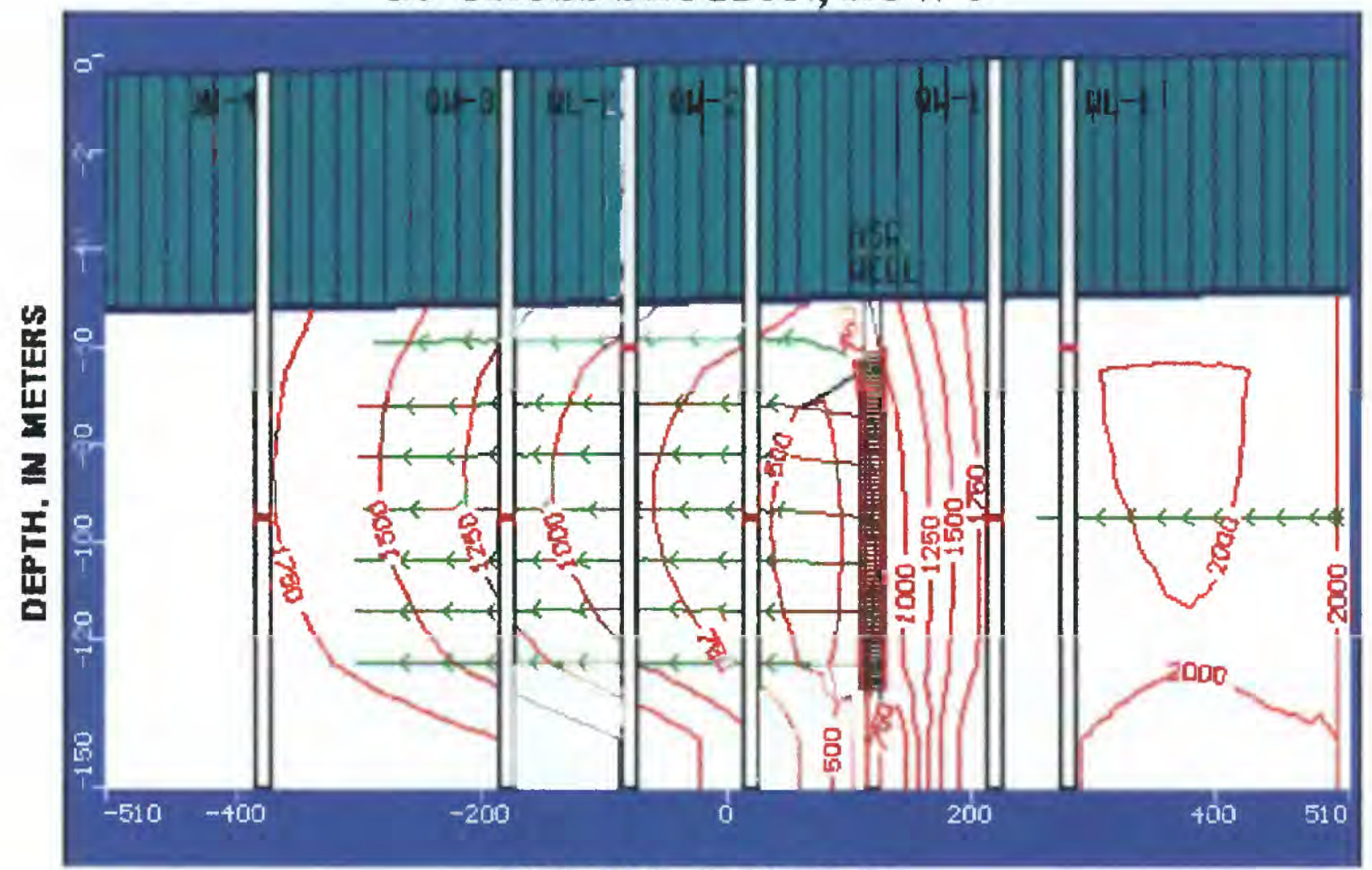

DISTANCE, IN METERS

Figure 8. Simulated heads, dissolved-solids concentrations, and flow pathlines after 2,000 days and eight aquifer storage recovery cycles in the well model. 


\section{A. 1,950 DAYS: END OF EIGHTH 200-DAY INJECTION PHASE}

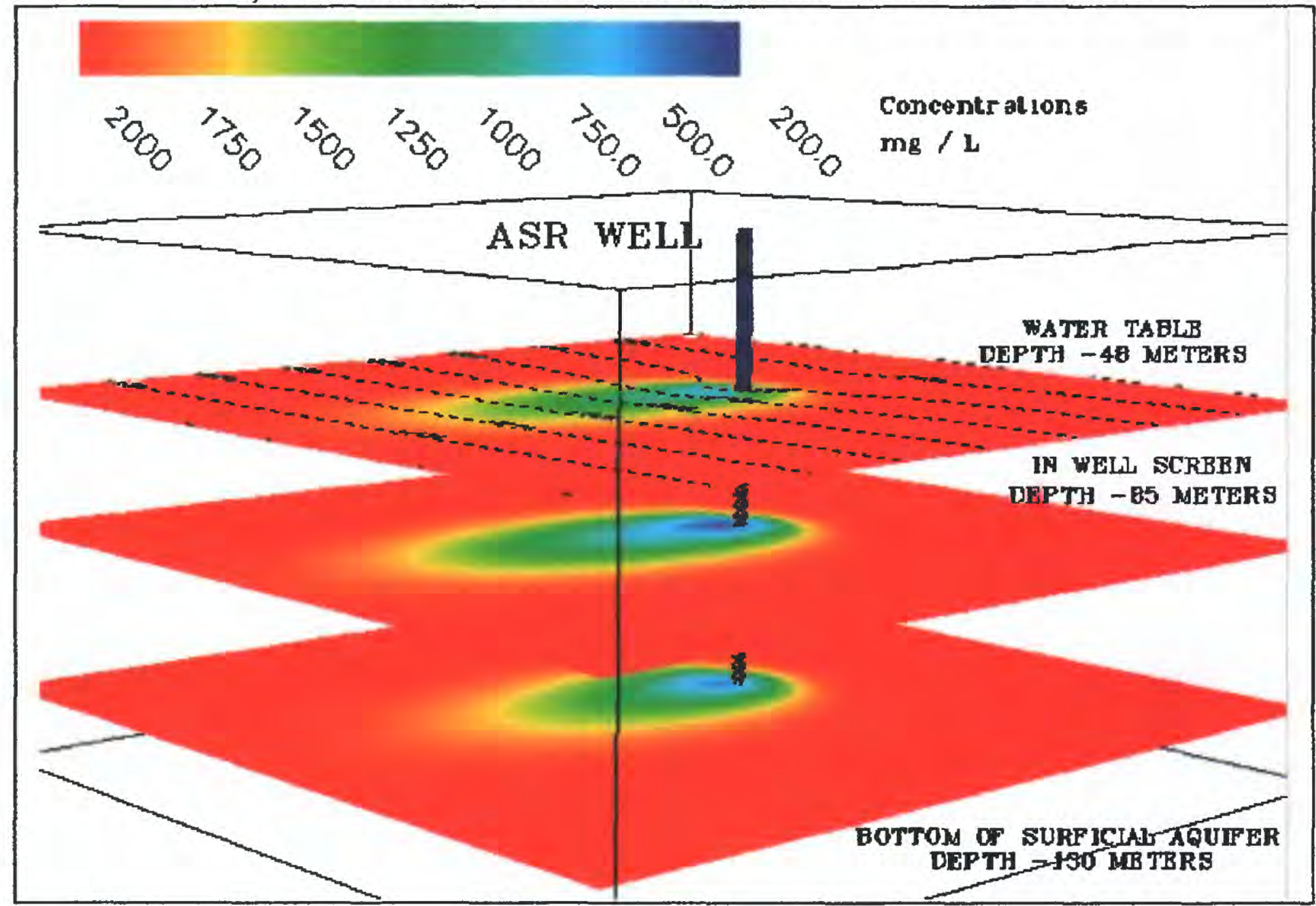

B. 2,000 DAYS: END OF EIGHTH 50-DAY RECOVERY PHASE

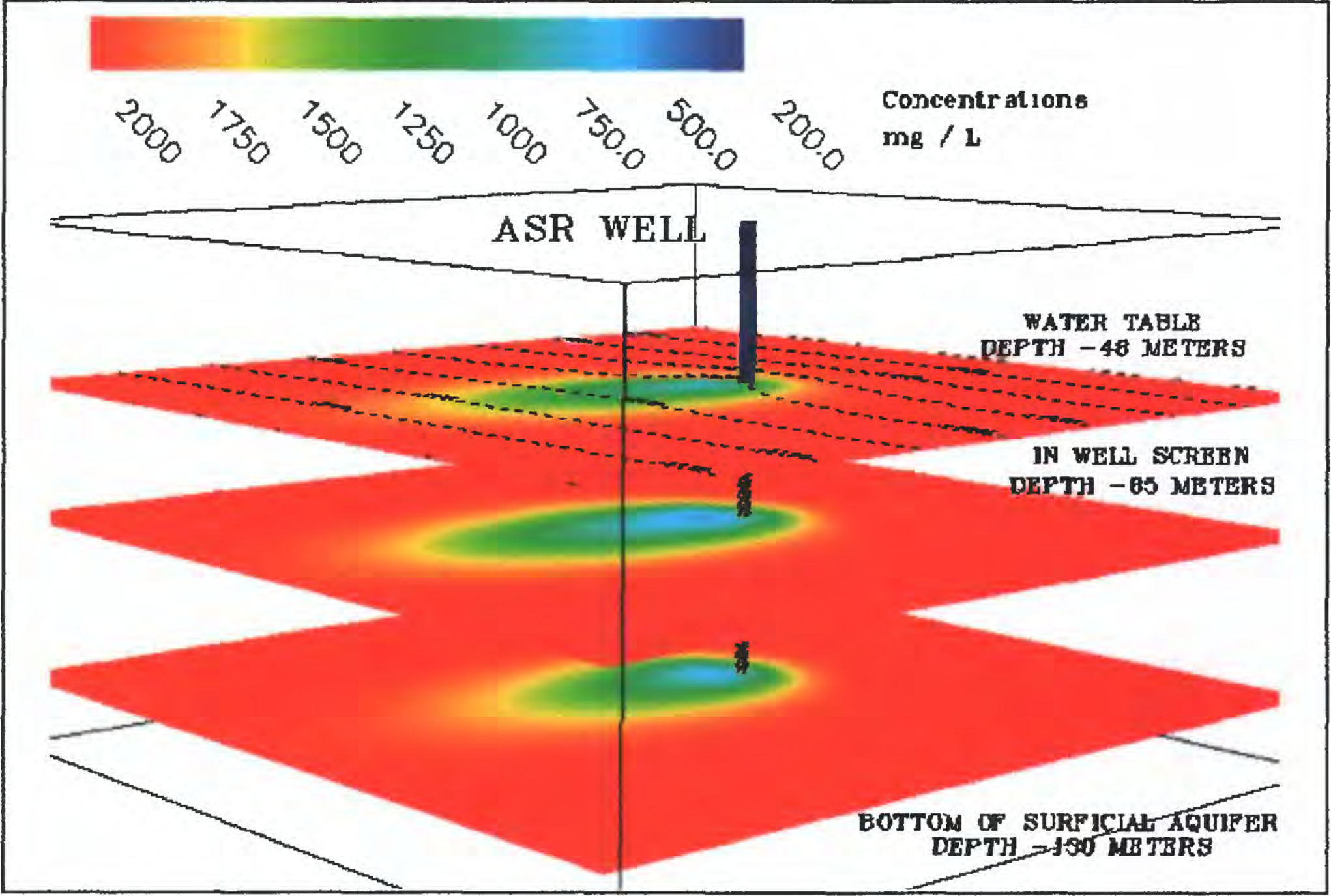

Figure 9. Visualization of the water table and dissolved-solids concentrations in the surficial aquifer system at the end of eight cycles of simulated storage (A) and recovery (B) of desalinated seawater in the well model. 
Visualization scenes of the well model of ASR are shown in figure 9. The visualization program displays the progressive simulated positions of the water-table contours and the plume of injected desalinated water for selected times defined in and saved by the ground-water model. For illustrative purposes, horizontal-slice views of the injected plume at selected depths after 1,950 and 2,000 days of cyclic ASR are shown. These times represent ground-water conditions at the peak and trough of the last ASR cycle (fig. 7). The visualizations show that the water table is elevated at the ASR well at the end of the last storage phase (fig. 9A) and freshwater is distributed fairly evenly in the three slices around the well, which indicates that injection is uniformly distributed through the total thickness of the aquifer. At the end of the last recovery phase, there is a water-table depression around the ASR well and TDS concentrations have increased (fig. 9B).

The well model simulated total injection of $1,600,000$ cubic meters of desalinated water and recovery of 400,000 cubic meters of mixed water. After eight cycles of injection and recovery, an egg-shaped plume of fresher water with a TDS concentration less than native ground remained in the aquifer and extended from just upgradient of the ASR well to the downgradient boundary of the model. A 100,000-square-meter area (10 hectares) contained water with a TDS concentration less than $1,500 \mathrm{mg} / \mathrm{L}$. Multiplying by the aquifer thickness ( 80 meters) and specific yield $(0.15)$, the total reserve of freshwater after 2,000 days of ASR was estimated to be 1,200,000 cubic meters.

\section{Pond Model}

The pond model consisted of simulating an infiltration pond 60-meters-square $(9$ model cells) upgradient of the middle of the aquifer block (fig. 10). A recovery well, screened in the upper three-quarters of the aquifer between depths of 60 and 110 meters, was located 50 meters downgradient from the edge of the pond. The simulated ASR consisted of adding recharge directly to the water table at a rate of 0.28 meters per day $(1,000$ cubic meters per day) for 245 days, then stopping recharge and pumping at a rate of 1,000 cubic meters per day for 120 days on a cyclic schedule for 1,825 days ( 5 years). One cycle reflects a hypothetical year-long case where excess desalinated water is stored in the aquifer during the off-season and recovered during the peak-season. As in the well model, much more water was stored than recovered to test the feasibility of augmenting the ground-water reservoir while withdrawing small quantities for peak-season use.

Graphs of simulated water-level and water-quality in observation wells are shown in figure 11. The upper graph shows water-levels in two observation wells, 90 meters upgradient (WL-1) and 210 meters downgradient (WL-2) of the infiltration pond and 200 meters upgradient and 160 meters downgradient of the recovery well, respectively. The lower graph shows TDS concentrations in the aquifer at a depth equal to the middle of the ASR well screen (about 85 meters below land surface) in the ASR recovery well and four quality-of-water monitoring wells located 60 meters upgradient (QW-1) and between 100 and 500 meters downgradient (QW-2, QW-3, and QW-4) of the infiltration pond. The graphs show the cyclic nature of the simulated storage and recovery by half-meter fluctuations in water levels and by stepped TDS concentrations in the nearest QW wells. The QW wells also indicate a progressive decrease in simulated TDS concentration as 200 $\mathrm{mg} / \mathrm{L}$ water is added to the system and moves downgradient toward well QW-4. In the first recovery phase between 245 and 365 days, the TDS concentration increased from 1,200 to $1,400 \mathrm{mg} / \mathrm{L}$. In subsequent recovery phases, TDS concentrations increased as recovery progressed, but they remained below $1,000 \mathrm{mg} / \mathrm{L}$. It may be implied from the graph that fresh ground water would migrate from the pond to the downgradient recovery well in about 500 days (two storage phases). 
The simulated plume of freshwater after 1,825 days ( 5 cycles) of ASR is shown in figure 12. The simulated plume is characterized by both lateral and vertical TDS concentration gradients, which result from a lens of freshwater introduced to the surface of the brackish system. The thickness of the plume is greatest beneath the infiltration pond as shown in the cross-sectional view. The interface between the infiltrated freshwater and the native brackish water is relatively sharp upgradient of the pond because inflow of $2,000 \mathrm{mg} / \mathrm{L}$ water from the boundary pushed the interface toward the pond. Downgradient and beneath the pond, the interface is wide due to advection in the downgradient direction, dispersion, and back and forth mixing during ASR cycles. Ground-water pathlines indicate that the leading edge of the freshwater moved a little more than 400 meters downgradient from the pond. Pathlines from the upgradient boundary indicate that native ground water moved about 300 meters.

Visualization results for the pond model of ASR include simulated water-table contours and horizontal slices that depict TDS concentrations through the plume of desalinated water beneath the infiltration pond (fig. 13). Views of the simulated infiltration plume after 1,705 and 1,825 days of cyclic ASR are shown. These times represent ground-water conditions at the peak and trough of the last ASR cycle (fig. 11). The visualizations show that the water table is elevated at the pond at the end of the last storage phase and freshwater is distributed fairly evenly around the recovery well, which indicates that the downgradient well is correctly placed (fig. 13A). At the end of the last recovery phase, there is a water-table depression around the recovery well and TDS concentrations have increased (fig. 13B). The freshwater lens is unevenly distributed in the three horizontal slices. The lens covers a large area at the water table, is much reduced at a depth of 85 meters (center of the recovery well screen), and is absent at the bottom of the aquifer.

The infiltration pond ASR scenario simulated storage of $1,225,000$ cubic meters of desalinated water and recovery of 600,000 cubic meters of mixed water. The model simulated a lens-shaped plume of fresher water with a TDS concentration less than native ground water remaining in the aquifer from just upgradient of the infiltration pond to the downgradient boundary of the model. An 88,000-square-meter area ( 8.8 hectares) containing water with a TDS concentration less than $1,500 \mathrm{mg} / \mathrm{L}$ was simulated. Multiplying area by the average lens thickness ( 50 meters) and specific yield ( 0.15$)$, the total reserve of freshwater after 1,825 days of ASR was estimated to be 660,000 cubic meters.

The concept of ASR by means of an infiltration pond raises important points that need to be addressed. In a field situation, the bottom of the pond could be about 40 meters above the water table. The model, however, considers the pond to be connected directly to the water table. For this to occur, the pond would have to be an unlikely 50 meters deep. Such problems as chemical reactions or thin beds of low-permeability in the unsaturated zone could change the quality of the water, permeability of the unsaturated zone, or the efficiency of infiltration.

Another issue to be dealt with is the potential for bacterial contamination of the pond water by wildlife or airborne microbes. Bacteria levels of recovered water would need to be monitored and chlorination might be required before use as a public supply.

The high rate of evaporation that would take place at the pond surface further complicates the pond analysis. The average evaporation rate at Al Ain totals about 3.32 meters per year (United Arab Emirates University, 1993, plate 44). If this number is applied to the 1,225 days (3.36 years) of infiltration simulated in the pond model, evaporation from the 3,600-square-meter pond would total about 40,000 cubic meters. This loss is about 3 percent of the $1,225,000$ cubic meters fed into the pond. 
A. PLAN VIEW

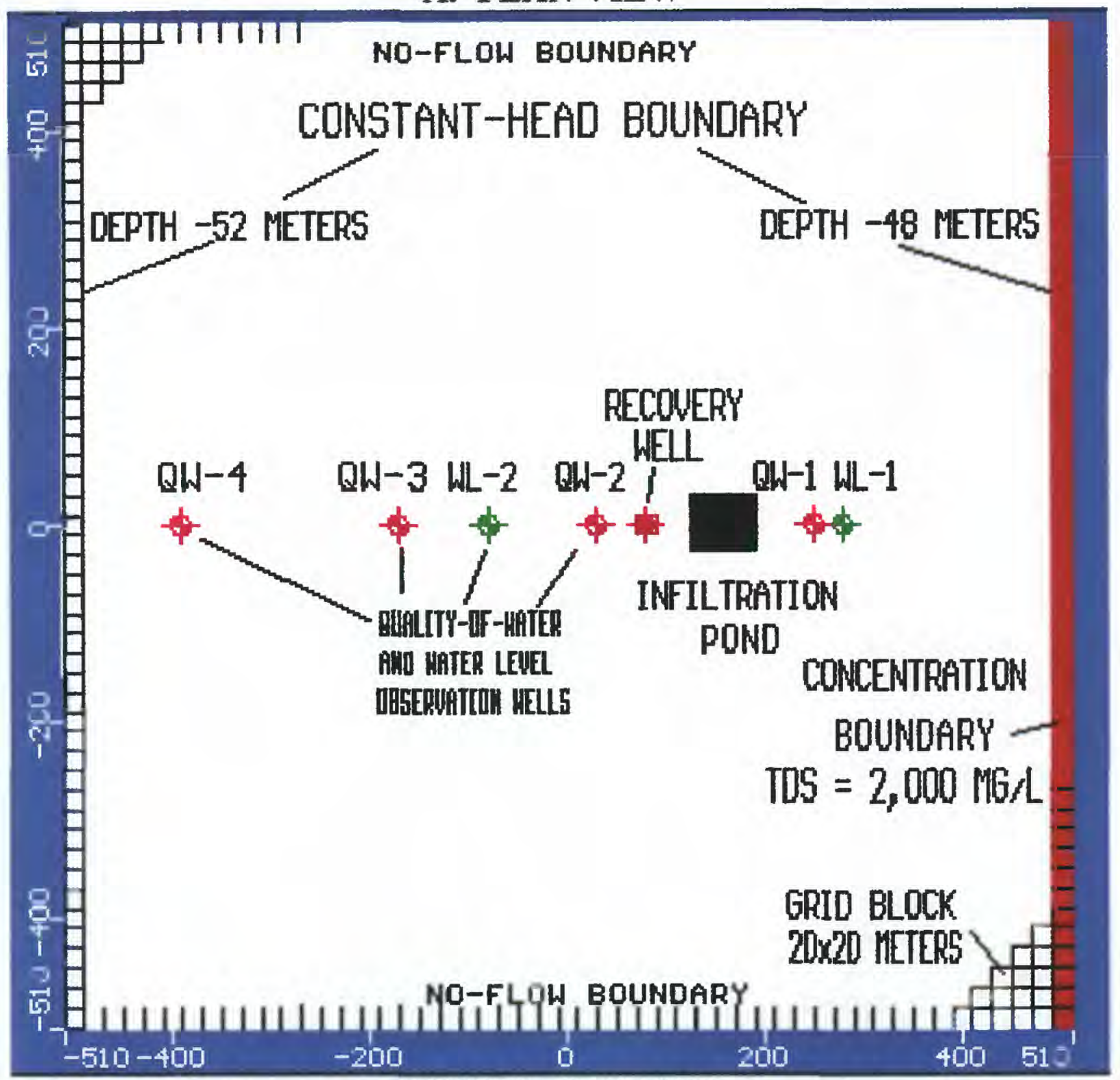

DISTANCE, IN METERS

B. CROSS SECTION, ROW 0

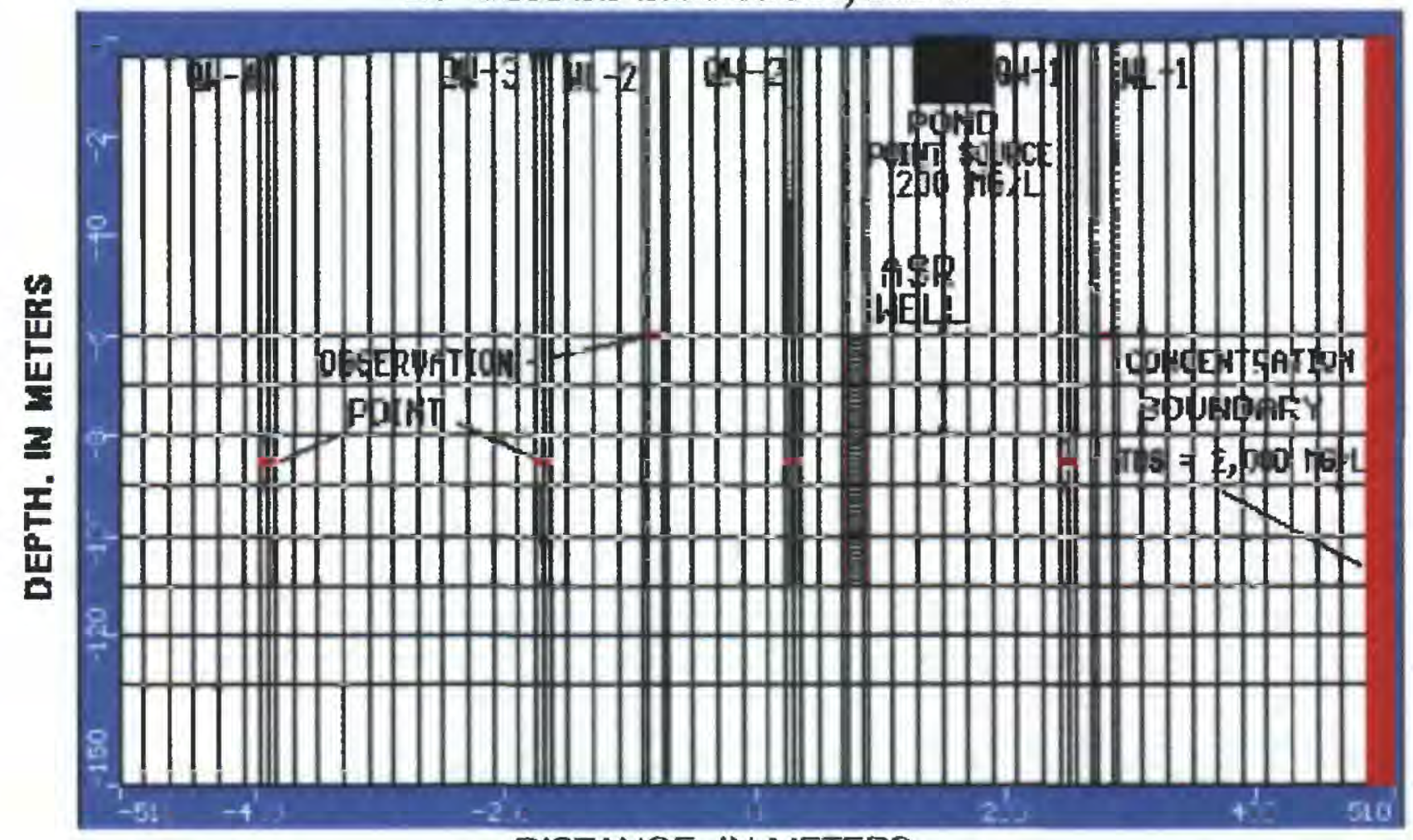

DISTANCE, IN METERS

Figure 10. Aquifer storage recovery pond model grid and boundary conditions. 

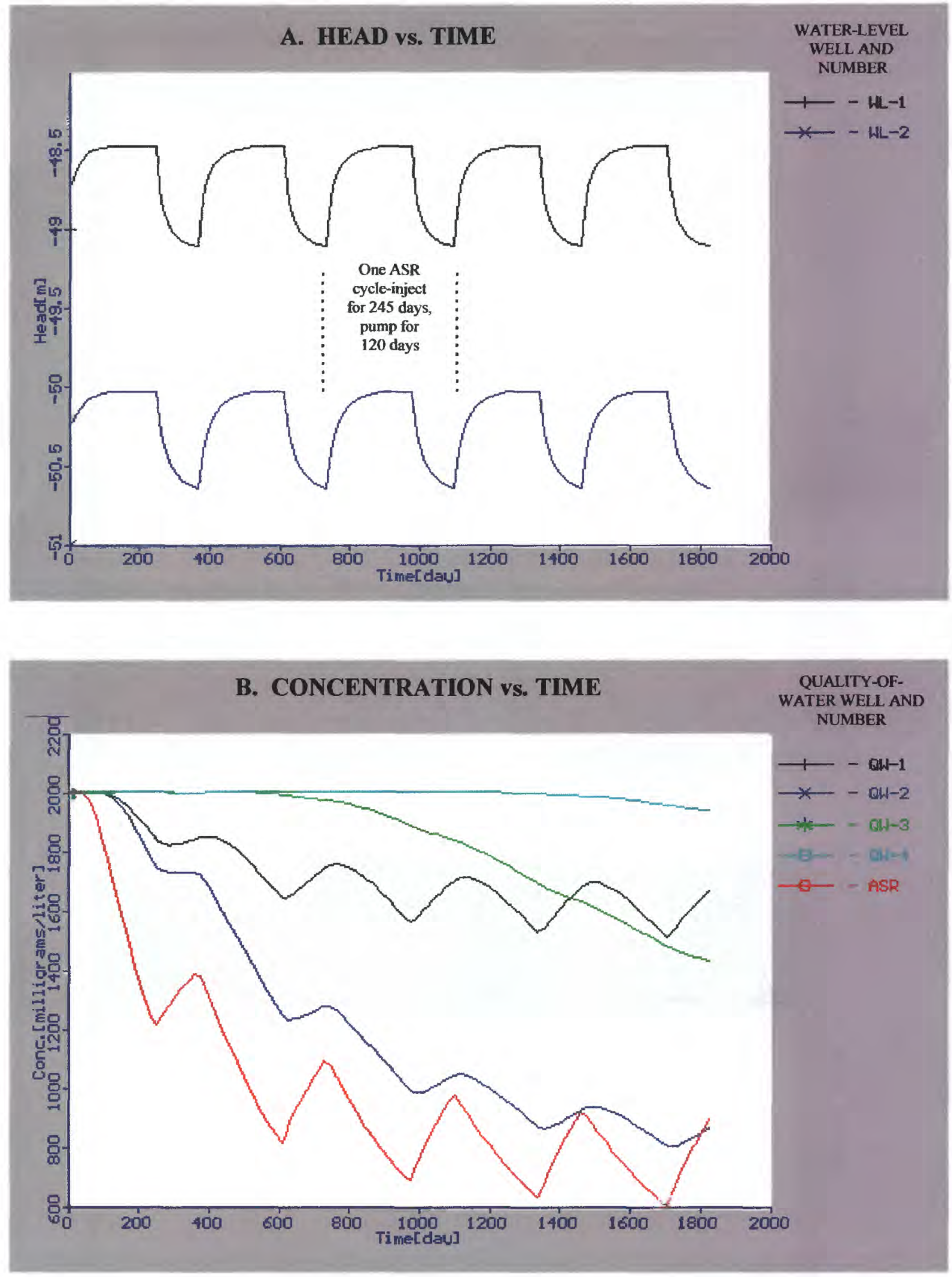

Figure 11. Simulated head (A) and dissolved-solids concentration (B) in observation wells for multiple aquifer storage recovery cycles of pond infiltration and pumping one well in the pond model. 


\section{A. PLAN VIEW, LAYER 4, DEPTH 85 METERS}

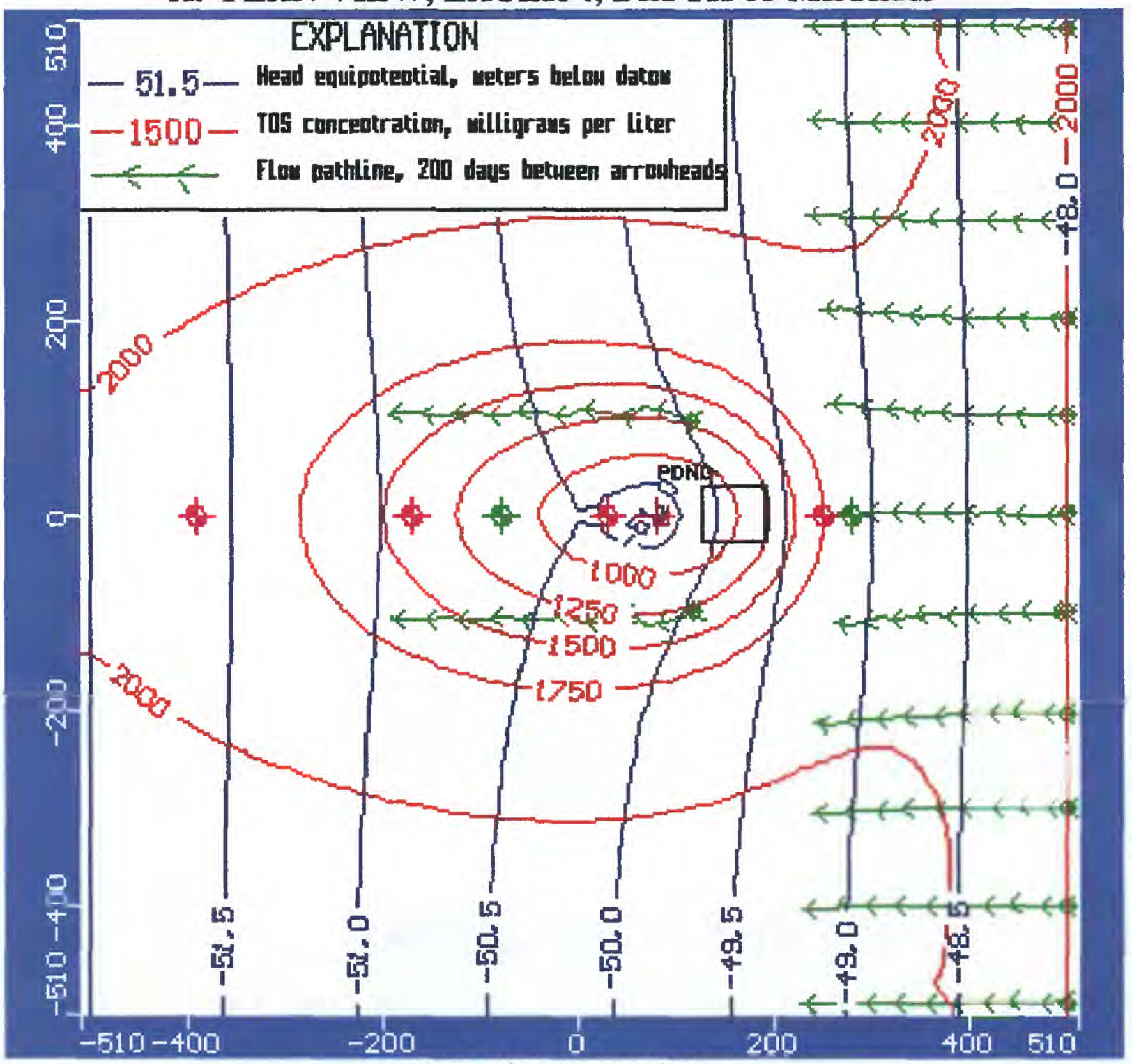

DISTANCE, IN METERS

B. CROSS SECTION, ROW 0

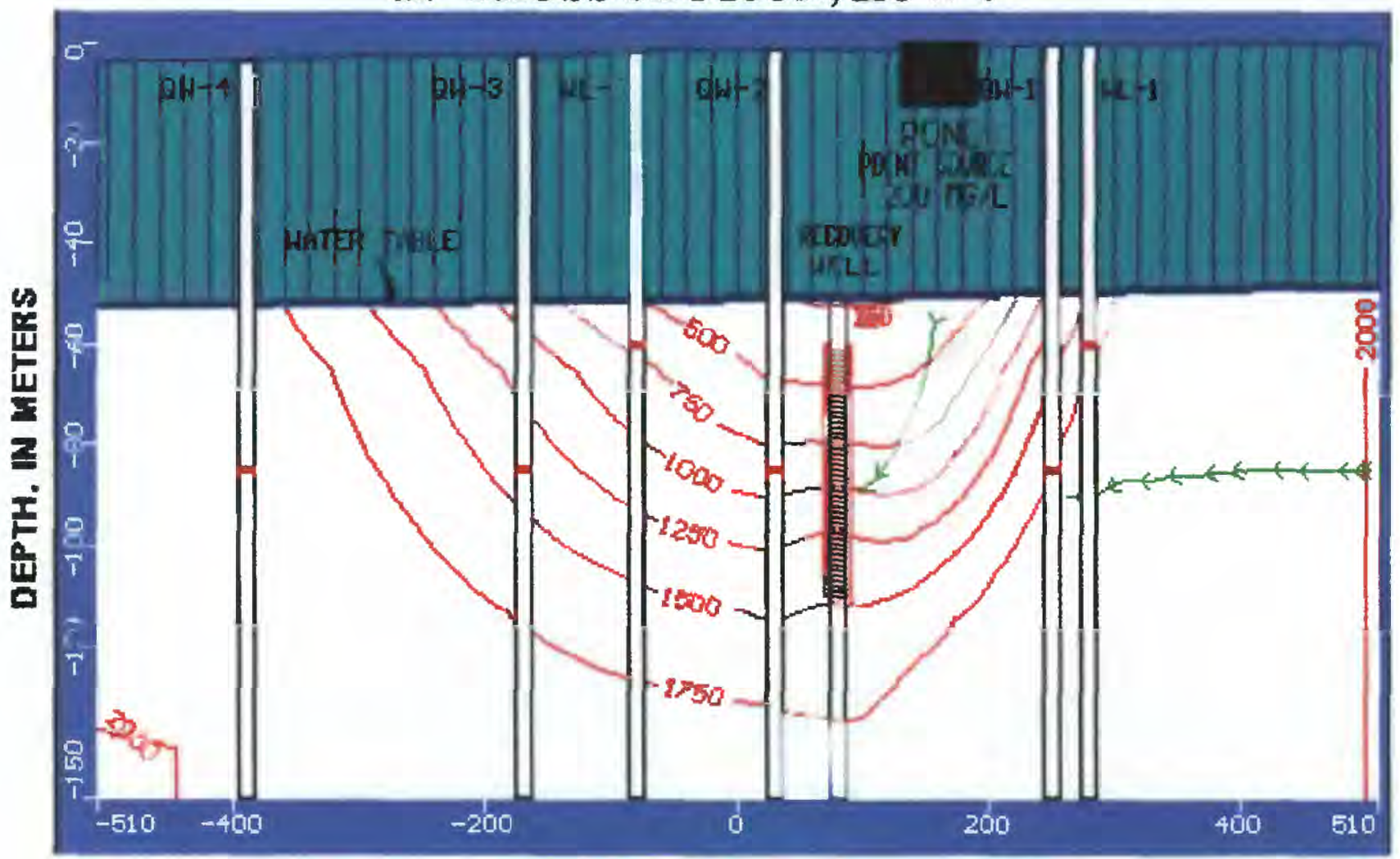

DISTANCE, IN METERS

Figure 12. Simulated heads, dissolved-solids concentrations, and flow pathlines after 1,825 days and five aquifer storage recovery cycles in the pond model. 
A. 1,705 DAYS: END OF FIFTH 245-DAY POND INFILTRATION PHASE

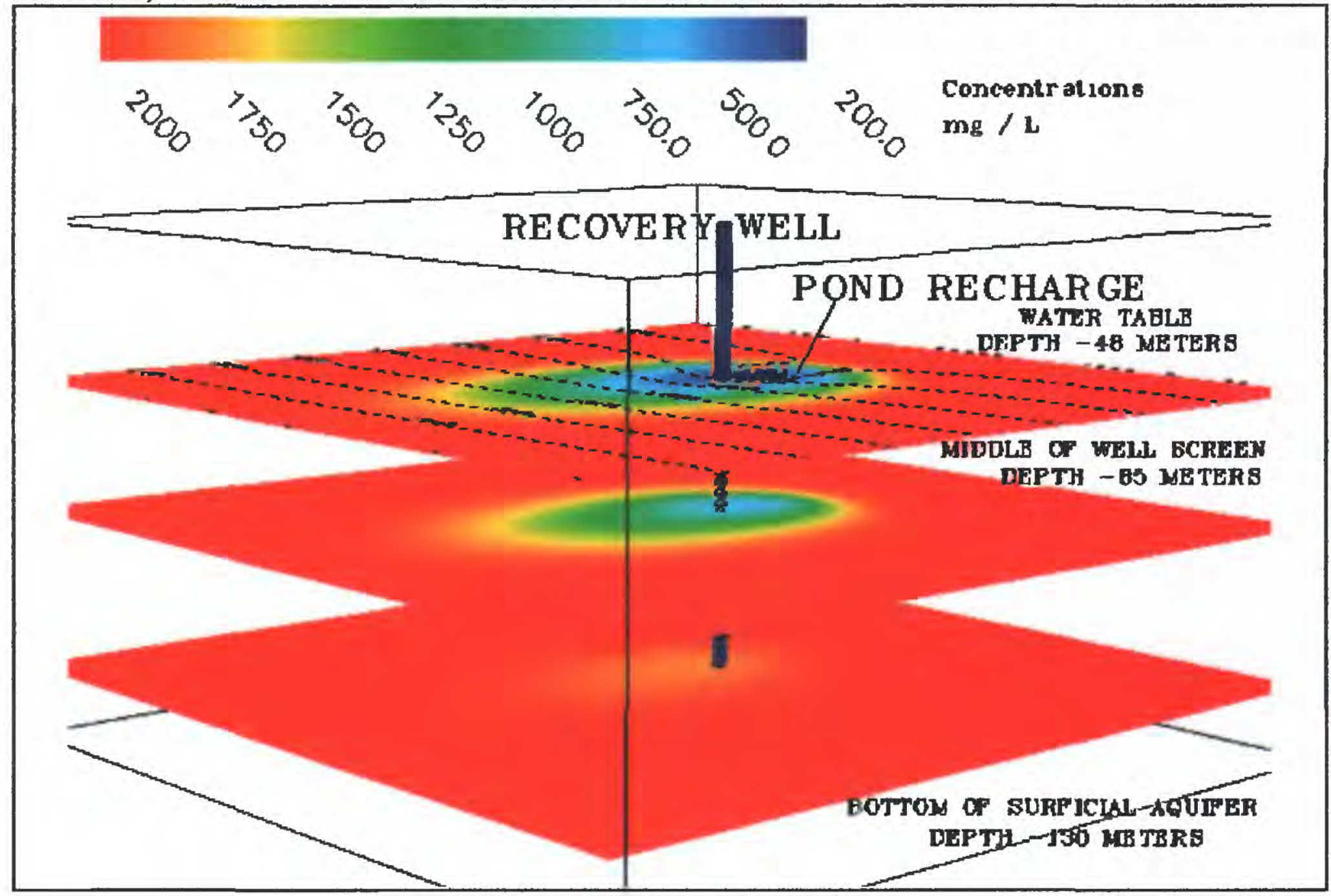

B. 1,825 DAYS: END OF FIFTH 120-DAY WELL RECOVERY PHASE

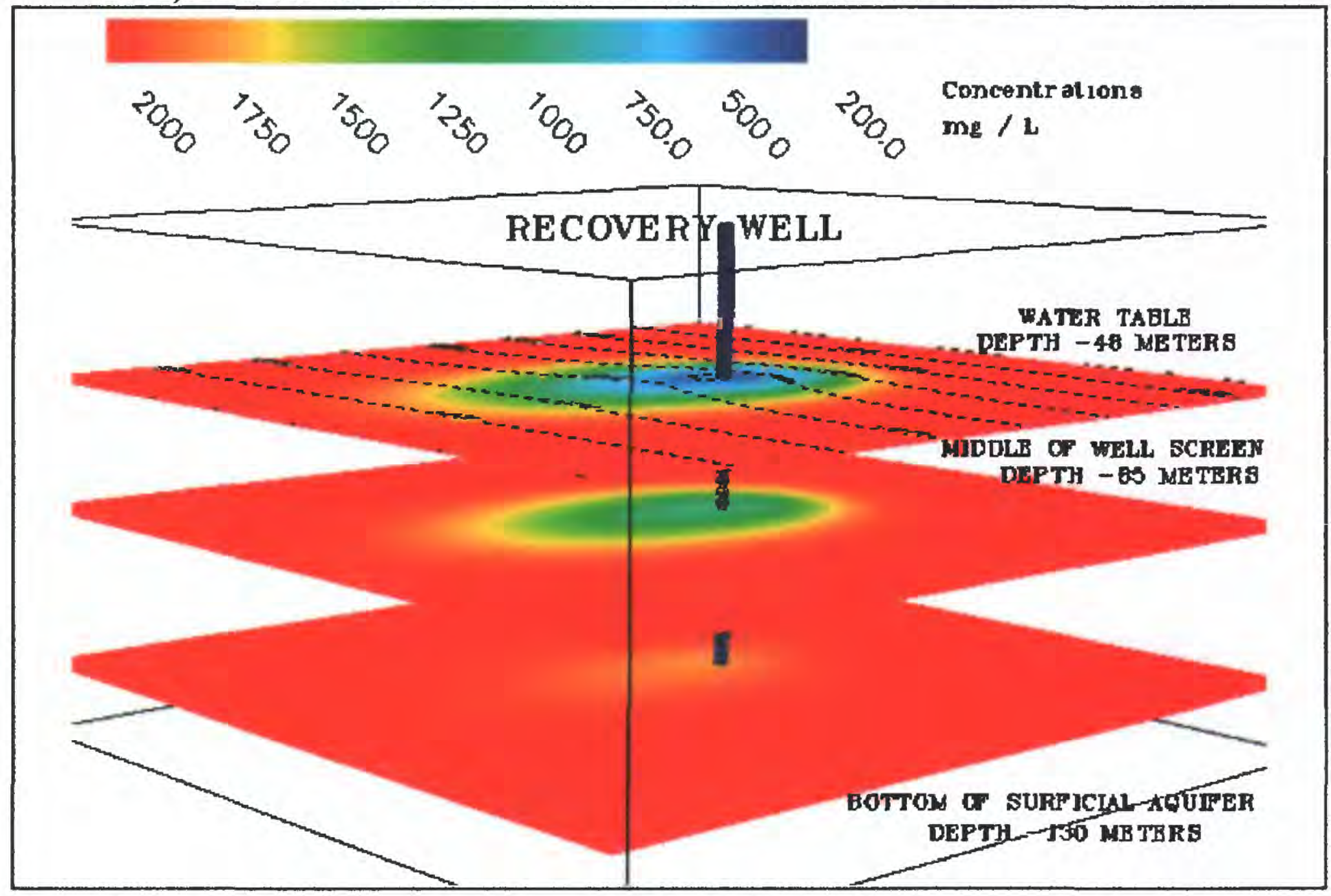

Figure 13. Visualization of the water table and dissolved-solids concentrations in the surficial aquifer system at the end of five cycles of simulated storage $(A)$ and recovery (B) of desalinated seawater in the pond model. 


\section{Strategic Reserve Model}

The strategic reserve model simulated an infiltration pond 60 -meters-square ( 9 model cells) upgradient of the middle of the aquifer block (fig. 14). Fifteen recovery wells, screened in the upper three-quarters of the aquifer between depths of 60 and 110 meters, were simulated in a fan-shaped zone between 50 and 370 meters downgradient from the edge of the pond. The simulation consisted of recharging the aquifer at a rate of 0.28 meters per day ( 1,000 cubic meters per day) for 1,095 days ( 3 years), pumping at a rate of 15,000 cubic meters per day for 10 days, and continuing recharge to the aquifer for 365 days. The hypothetical case demonstrates the feasibility of pumping a large volume of water for a short time from a strategic reserve should a coastal desalinization plant suddenly shut down. It is recognized that several facilities of this size would be required to provide uninterrupted service in the event of a plant shutdown. For example, 23 ASR facilities pumping 15,000 cubic meters per day would be required to provide the 346,000 cubic meters per day equivalent capacity of the Taweelah ' $B$ ' desalinization plant.

Simulation results for the strategic reserve model of ASR are shown in figures 1520. Water-level hydrographs are shown in figure 15 for two observation wells 100 meters upgradient (WL-1) and 450 meters downgradient (WL-2) of the infiltration pond and 220 meters upgradient and 80 meters downgradient of the recovery-well fan, respectively. Hydrographs are also shown for recovery wells R-2 and R-8. The simulated hydrographs show a rise of about 0.5 meter in the water table near the infiltration pond during the storage phase and a 2-meter decline in recovery wells during the 10-day recovery phase.

Graphs of simulated TDS concentrations are shown in figure 15 for the two quality-of-water monitoring wells and the central line of 5 recovery wells (R-2, R-5, R-8, R11, and R-14). The graphs represent simulated concentrations in the aquifer at a depth equal to the middle of the ASR well screens (about 85 meters below land surface). The QW wells indicate a progressive decrease in TDS concentration, representing freshening of the aquifer, as $200 \mathrm{mg} / \mathrm{L}$ water is added to the system and moves downgradient toward well QW-4. During the recovery phase between 1,095 and 1,105 days, TDS concentrations remained stable in all wells except the upgradient monitoring well (QW-1). The TDS concentration in this well increased from about 1,200 to 1,400 milligrams per liter, presumably due to inflow from upgradient. After 1,105 days, pond infiltration was resumed and freshening of the aquifer continued.

Simulated velocity fields are shown in figures 16 and 17 as areal views in the upper model layer and as cross-sections for the ends of the storage and recovery phases, respectively. At the end of the storage phase, simulated flow in the vicinity of the pond is radial outward and downward through the pond bed (fig. 16). Subsequently, the water moves downgradient with the superimposed regional flow field. The simulated maximum rate of ground-water flow is 1.2 meters per day in the vicinity of the pond where infiltration has simulated a rise in the water table and, hence, an increase in the hydraulic gradient. Velocity vectors decrease rapidly within a distance of two model cells (40 meters) from the pond. The regional flow rate is about 0.2 meters per day.

At the end of the recovery phase, the simulated velocity vectors at the water-table converge on the cone of depression in the water table caused by pumping from the recovery well field (fig. 17). The simulated maximum velocity is 1 meter per day. Velocities are highest between the infiltration pond and the nearest recovery wells, where the head gradient is the steepest. In the center of the well field, velocity directions are both upward and downward, indicating that some deep water is being drawn up into the partiallypenetrating recovery wells. 
The simulated plume of freshwater after 1,095 days, at the end of the 3-year storage cycle, is shown in figure 18. The plume is characterized by both lateral and vertical TDS concentration gradients, which result from a lens of freshwater introduced to the surface of the brackish system. The area of the simulated plume at a depth of 85 meters is about 105,000 square meters ( 10.5 hectares). The thickness of the simulated plume is greatest beneath the infiltration pond as shown in the cross-sectional view. The interface between the infiltrated freshwater and the native brackish water is relatively sharp upgradient of the pond because inflow of $2,000 \mathrm{mg} / \mathrm{L}$ water from the boundary pushes the simulated interface toward the pond. Downgradient and beneath the pond, the interface is wide due to advection in the downgradient direction and dispersion. Simulated groundwater pathlines indicate that the freshwater moved a little more than 500 meters downgradient from the pond. Simulated pathlines from the upgradient boundary indicate that the regional ambient ground-water moved about 150 meters over three years, which is equivalent to a lateral flow rate of 50 meters per year or 14 centimeters per day.

Simulated water levels, TDS concentrations, and ground-water flow pathlines at the end of the 10-day recovery cycle are shown in figure 19. A cone of depression about 2 meters deep has developed around the ASR recovery well field. The areal spread of the plume with a TDS concentration less than 1,500 milligrams per liter is about 105,000 square meters (10.5 hectares), which indicates that the 10-day pumping cycle did not significantly alter the configuration of the plume. Six recovery wells (R-10 to R-15) are outside the $1,500-\mathrm{mg} / \mathrm{L}$ concentration contour and produce brackish water. At the end of 10 days of pumping, the TDS concentration ranged between $390 \mathrm{mg} / \mathrm{L}$ in well R-2 and 1,860 $\mathrm{mg} / \mathrm{L}$ in wells $\mathrm{R}-13$ and $\mathrm{R}-15$. The TDS concentration of the blended water from all wells averaged about $1,100 \mathrm{mg} / \mathrm{L}$ and remained essentially unchanged during the 10 -day recovery period.

Visualization results for the storage and recovery phases of the strategic reserve model of ASR are shown in figure 20. Views of the simulated infiltration plume after 1,095 and 2,005 days of cyclic ASR are shown. These times represent ground-water conditions at the peak and trough of the ASR cycle (fig. 15). The visualizations show that the water table is elevated beneath the pond at the end of the 3-year-long storage phase (fig. 20A). The freshwater lens is unevenly distributed in the three horizontal slices. The lens covers a large area at the water table, is much reduced at a depth of 85 meters (center of the recovery well screens), and is absent at the bottom of the aquifer. At the end of the 10-day recovery phase, there is a water-table depression around the 15 recovery wells and there is no visually noticeable change in the size of the plume represented by a TDS concentration less than $2,000 \mathrm{mg} / \mathrm{L}$ (fig. 20B).

The strategic reserve ASR scenario simulated storage of $1,095,000$ cubic meters of desalinated water over a period of 1,095 days and recovery of 150,000 cubic meters of mixed water over a period of 10 days. A lens-shaped simulated plume of fresher water with a TDS concentration less than native ground water remained in the aquifer and extended from just upgradient of the infiltration pond to near the downgradient boundary of the model. A 105,000-square-meter area (10.5 hectares) contained water with a TDS concentration less than $1,500 \mathrm{mg} / \mathrm{L}$. Multiplying area by the average lens thickness $(50 \mathrm{me}-$ ters) and specific yield ( 0.15$)$, the total reserve of freshwater after 1,105 days of ASR was estimated to be 790,000 cubic meters. 
A. PLAN VIEW

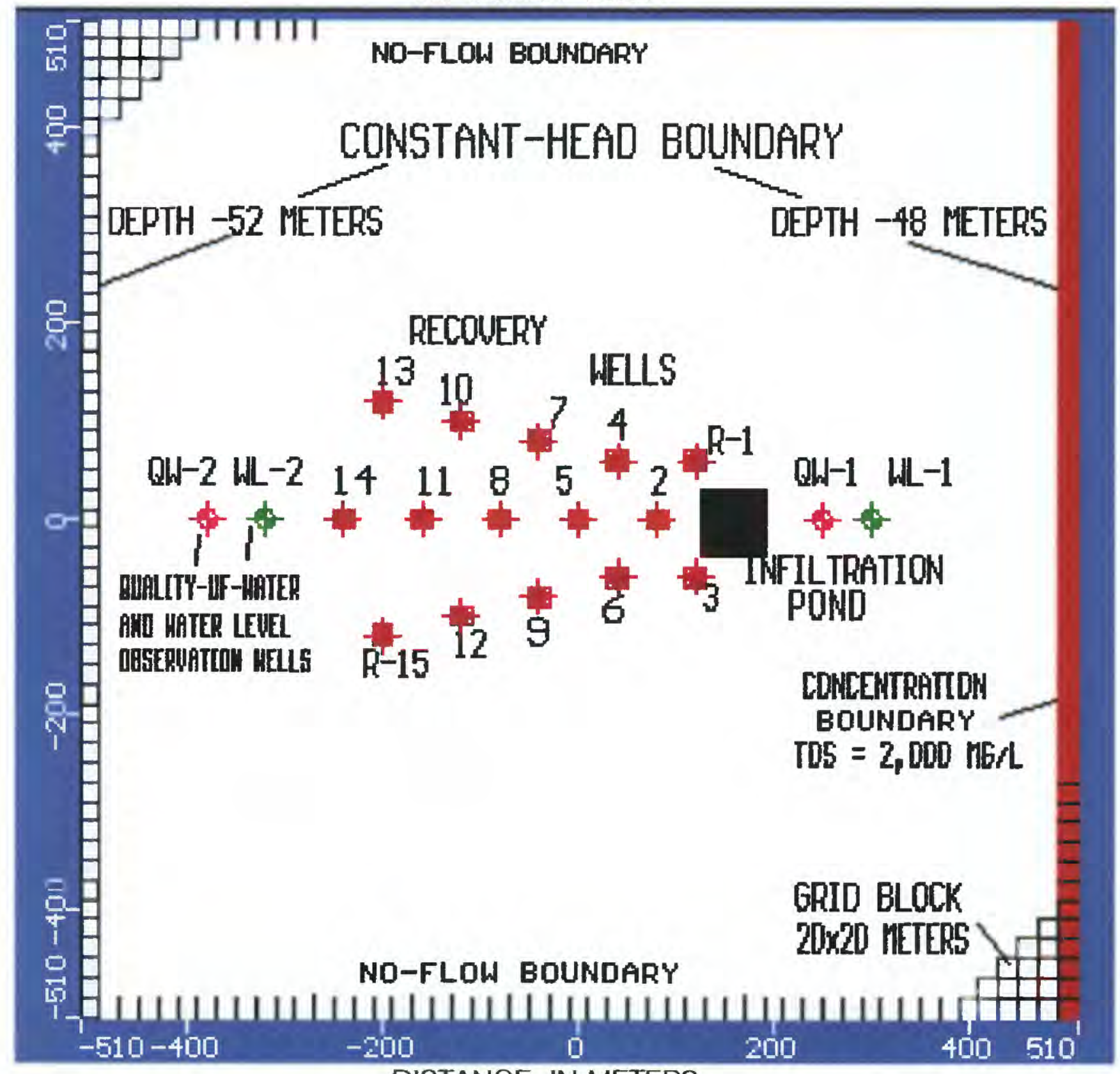

DISTANCE, IN METERS

B. CROSS SECTION, ROW 0

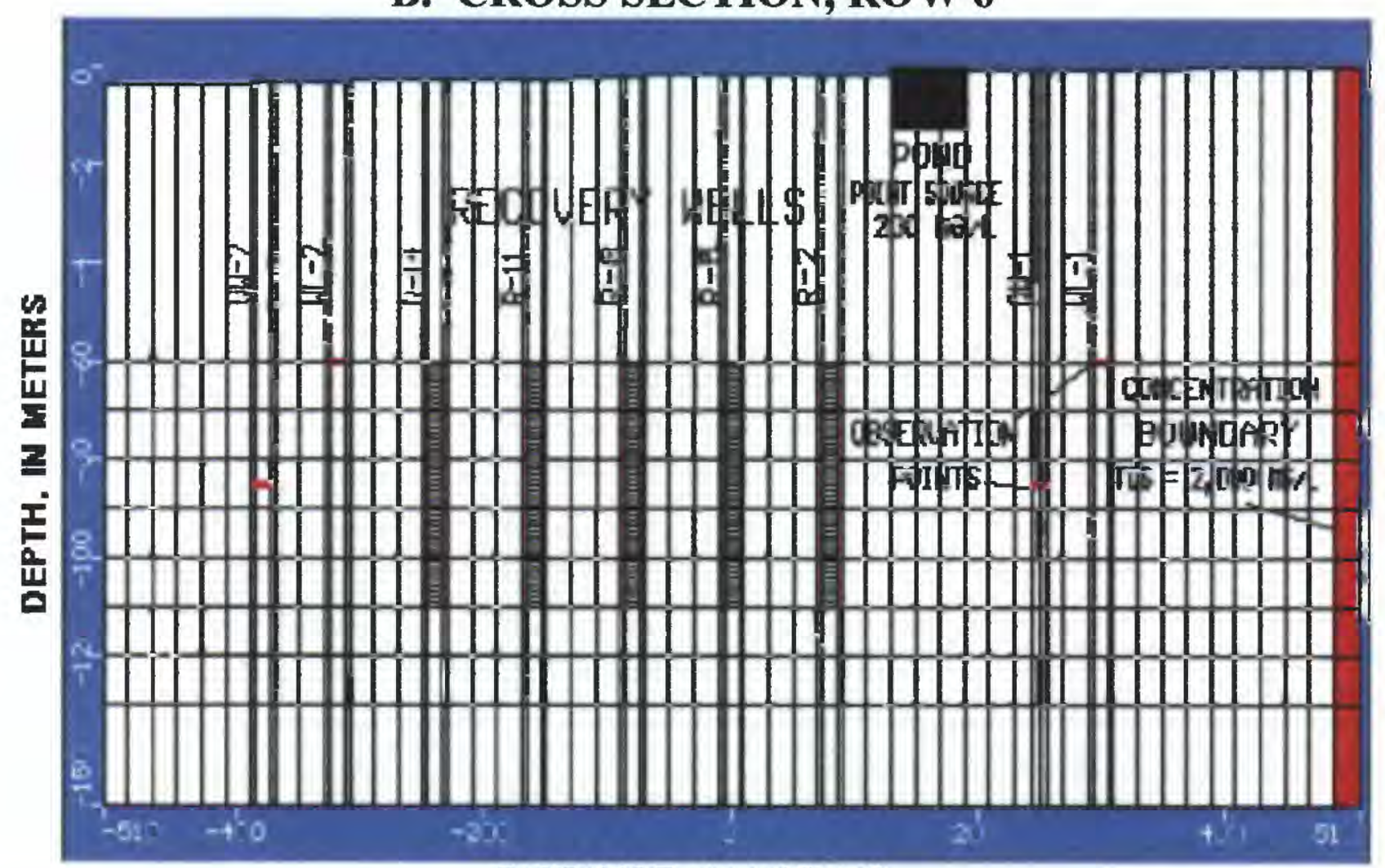

DISTANCE, IN METERS

Figure 14. Aquifer storage recovery strategic reserve model grid, well distribution, and boundary conditions. 

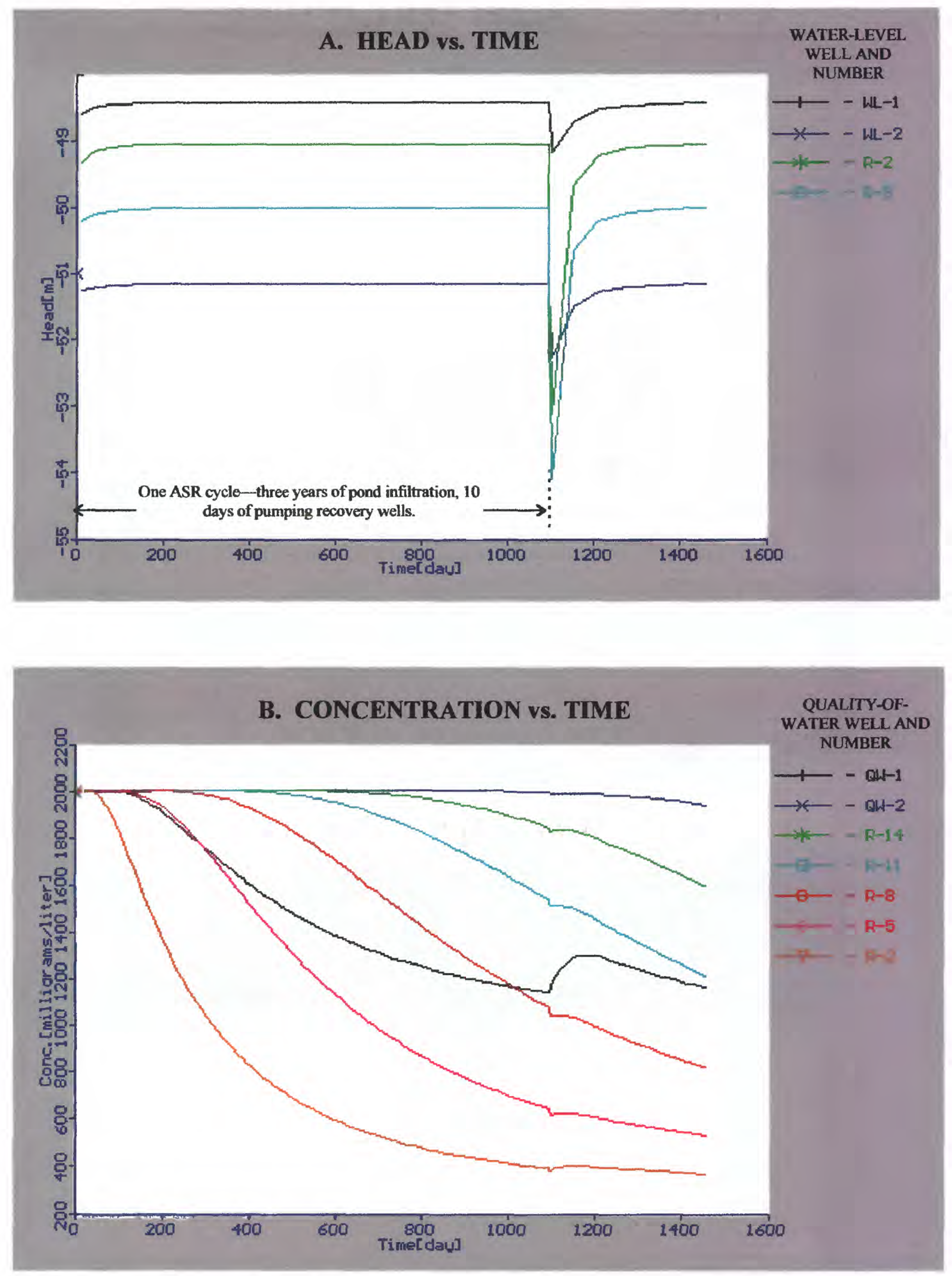

Figure 15. Simulated head and dissolved-solids concentration for one aquifer storage recovery cycle of pond infiltration and pumping 15 wells in the strategic reserve model. 
A. Plan View, Layer 1, at Water table

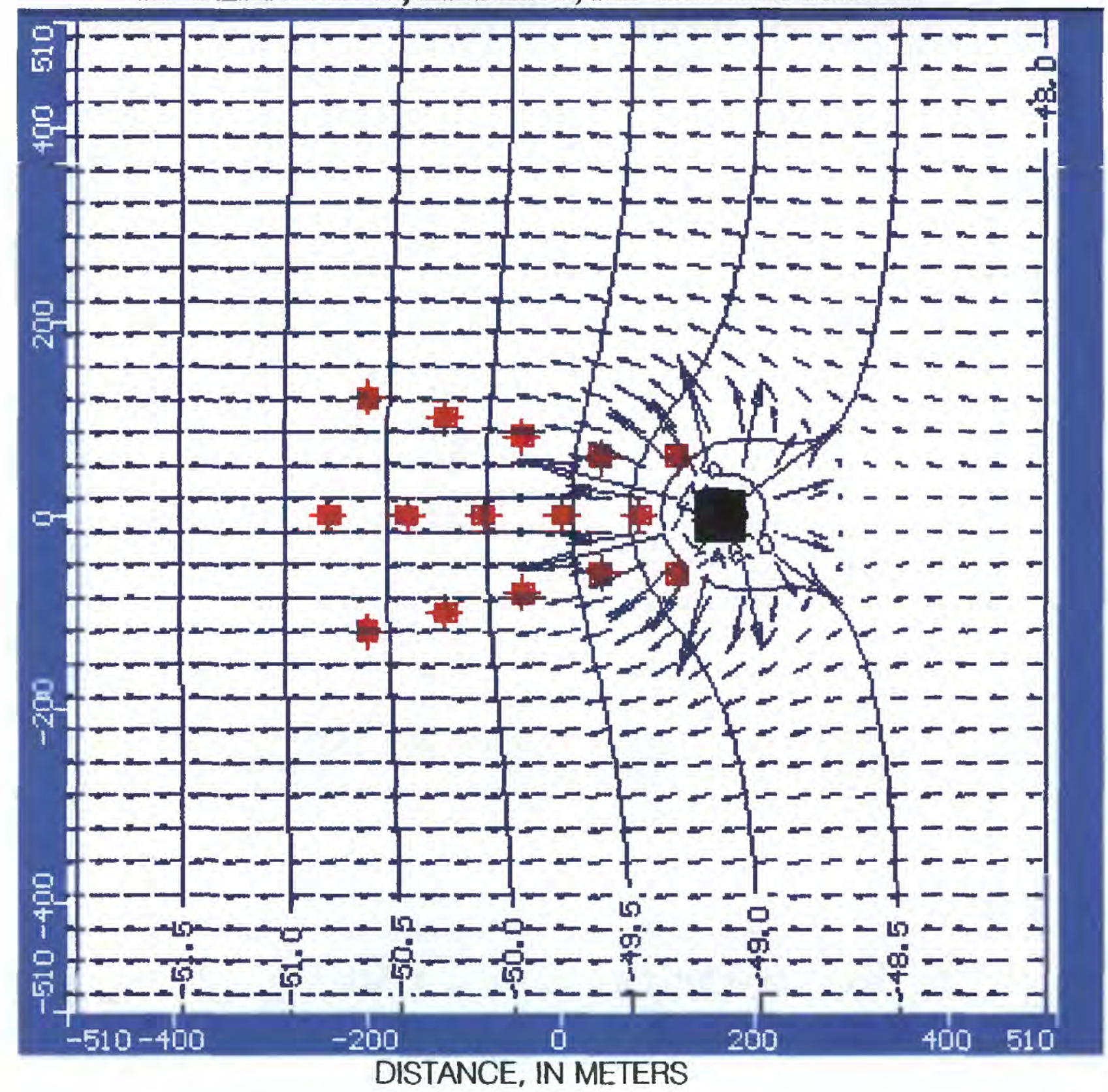

\section{B. CROSS SECTION, ROW 0}

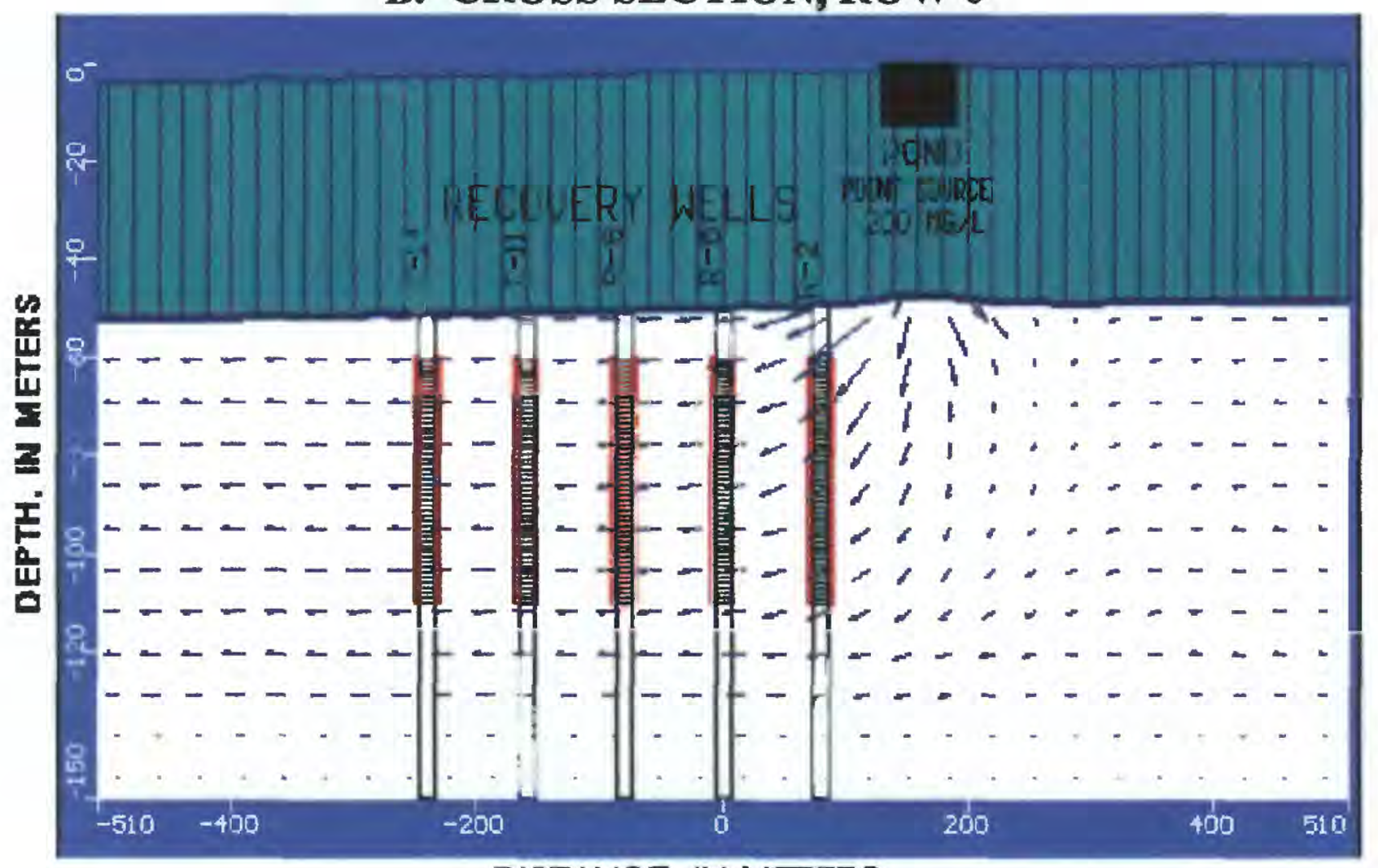

DISTANCE, IN METERS

Figure 16. Simulated ground-water velocity after 1,095 days (3 years) of recharging 1,000 cubic meters per day in the strategic reserve model. Maximum velocity represented by the longest arrow is 1.2 meters per day. 
A. PLAN VIEW, LAYER 1, AT WATER TABLE

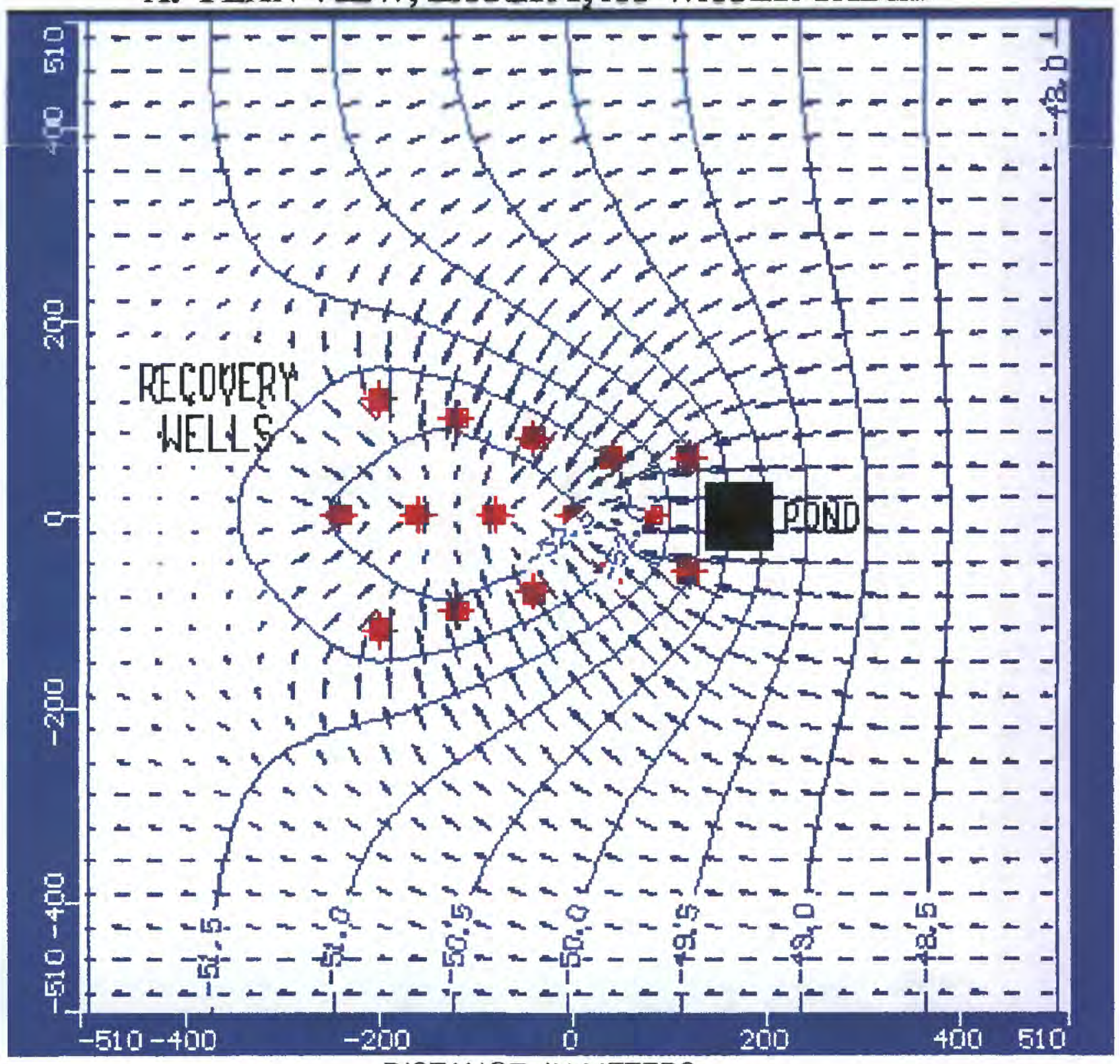

DISTANCE, IN METERS

\section{B. CROSS SECTION, ROW 0}

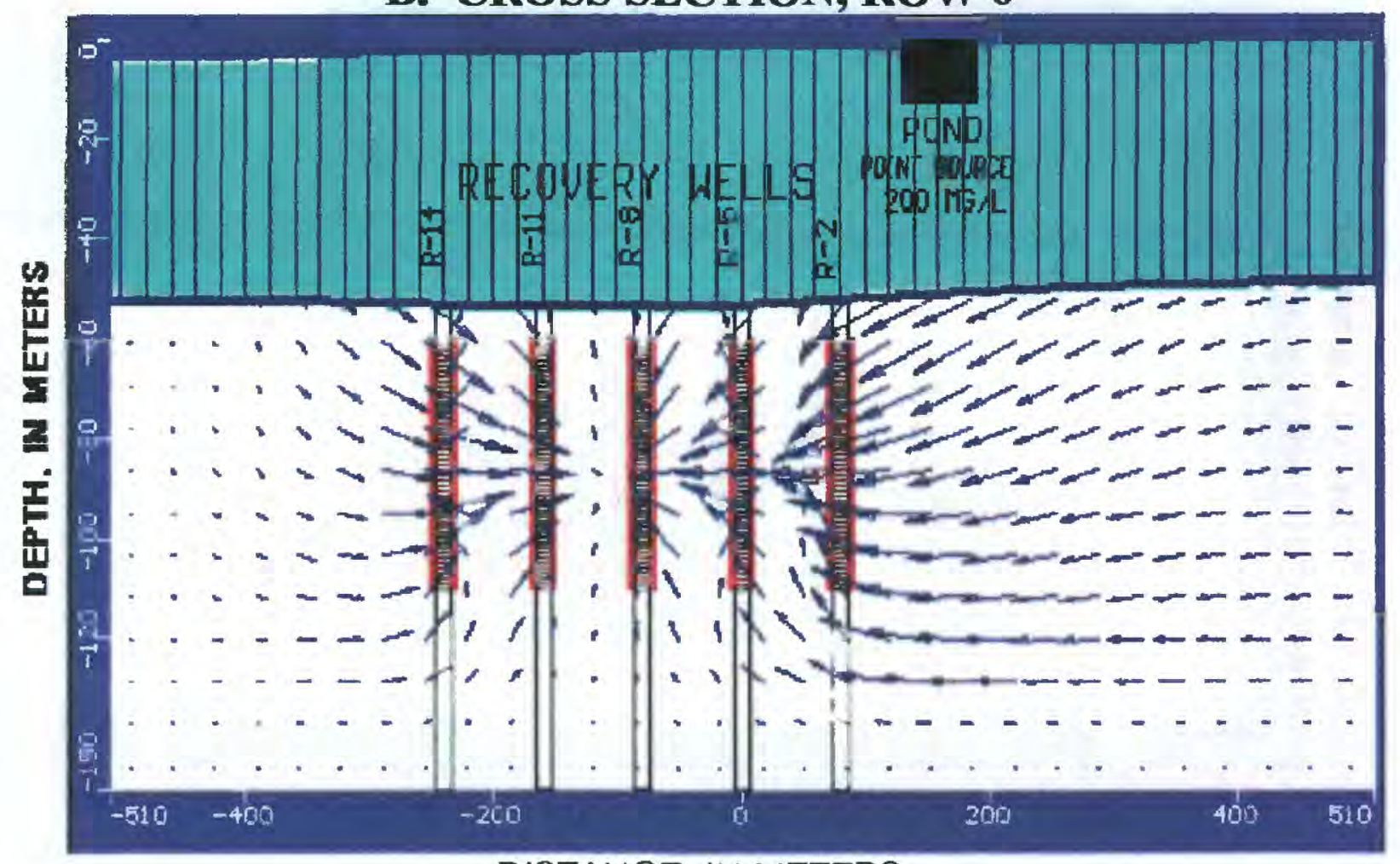

DISTANCE, IN METERS

Figure 17. Simulated ground-water velocity after 1,095 days (3 years) of recharging 1,000 cubic meters per day and 10 days of pumping 15,000 cubic meters per day in the strategic reserve model. Maximum velocity represented by the longest vector is 1 meter per day. 
A. PLAN VIEW, LAYER 4, DEPTH 85 METERS

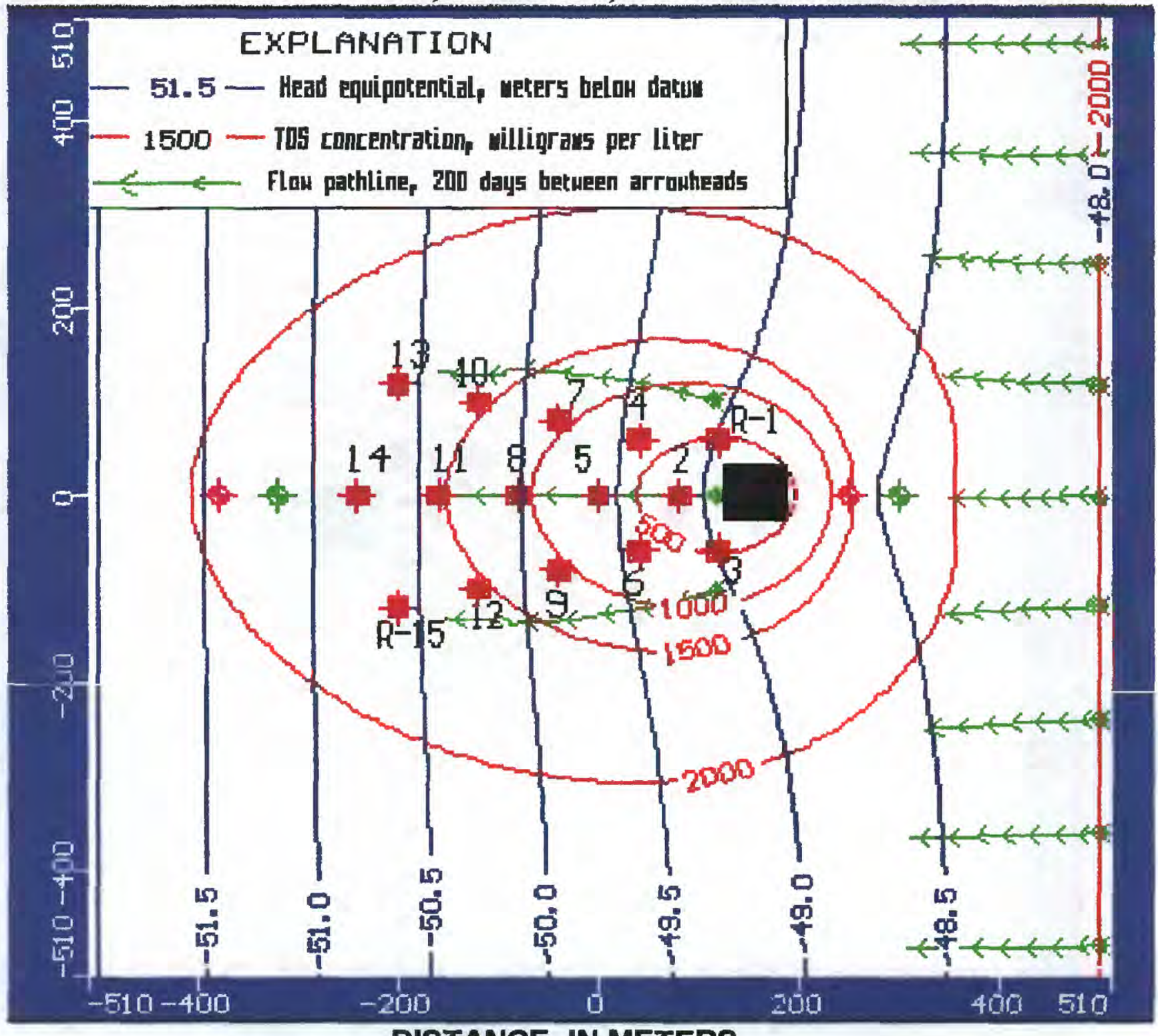

DISTANCE, IN METERS

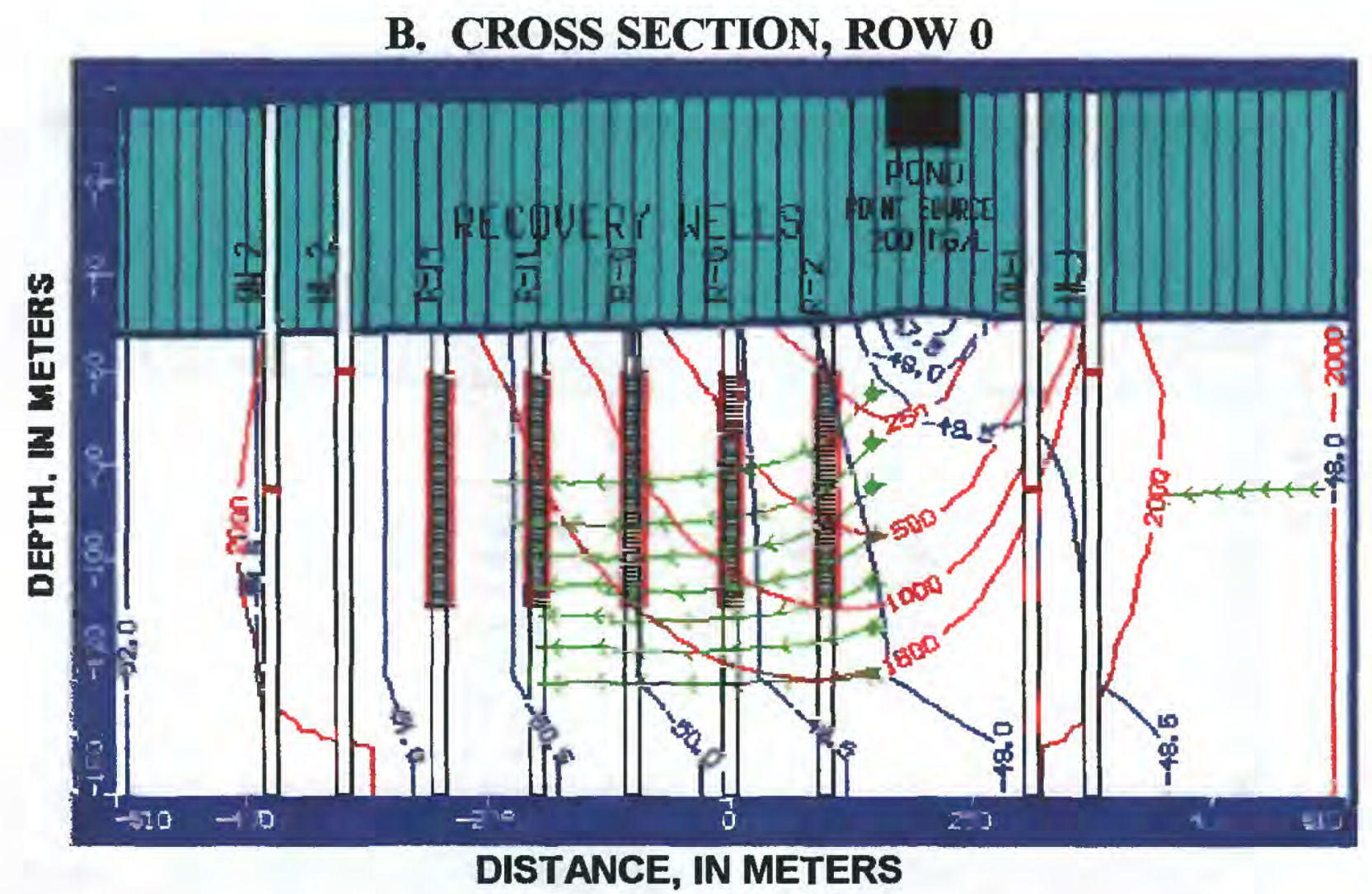

Figure 18. Simulated heads, dissolved-solids concentrations, and flow pathlines after 1,095 days (3 years) of recharging 1,000 cubic meters per day in the aquifer storage recovery strategic reserve model. 
A. PLAN VIEW, LAYER 4, DEPTH 85 METERS

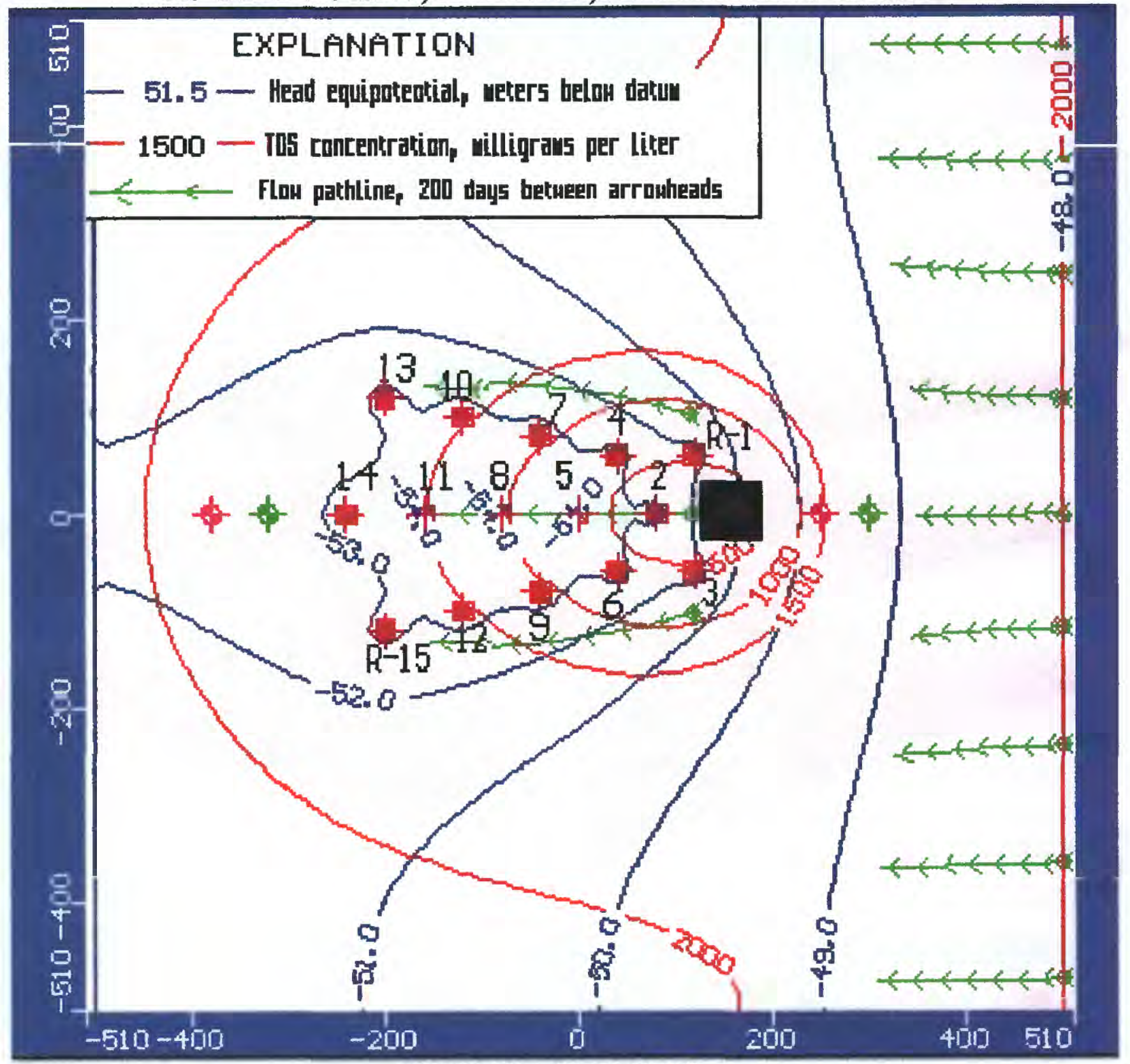

DISTANCE, IN METERS

B. CROSS SECTION, ROW O

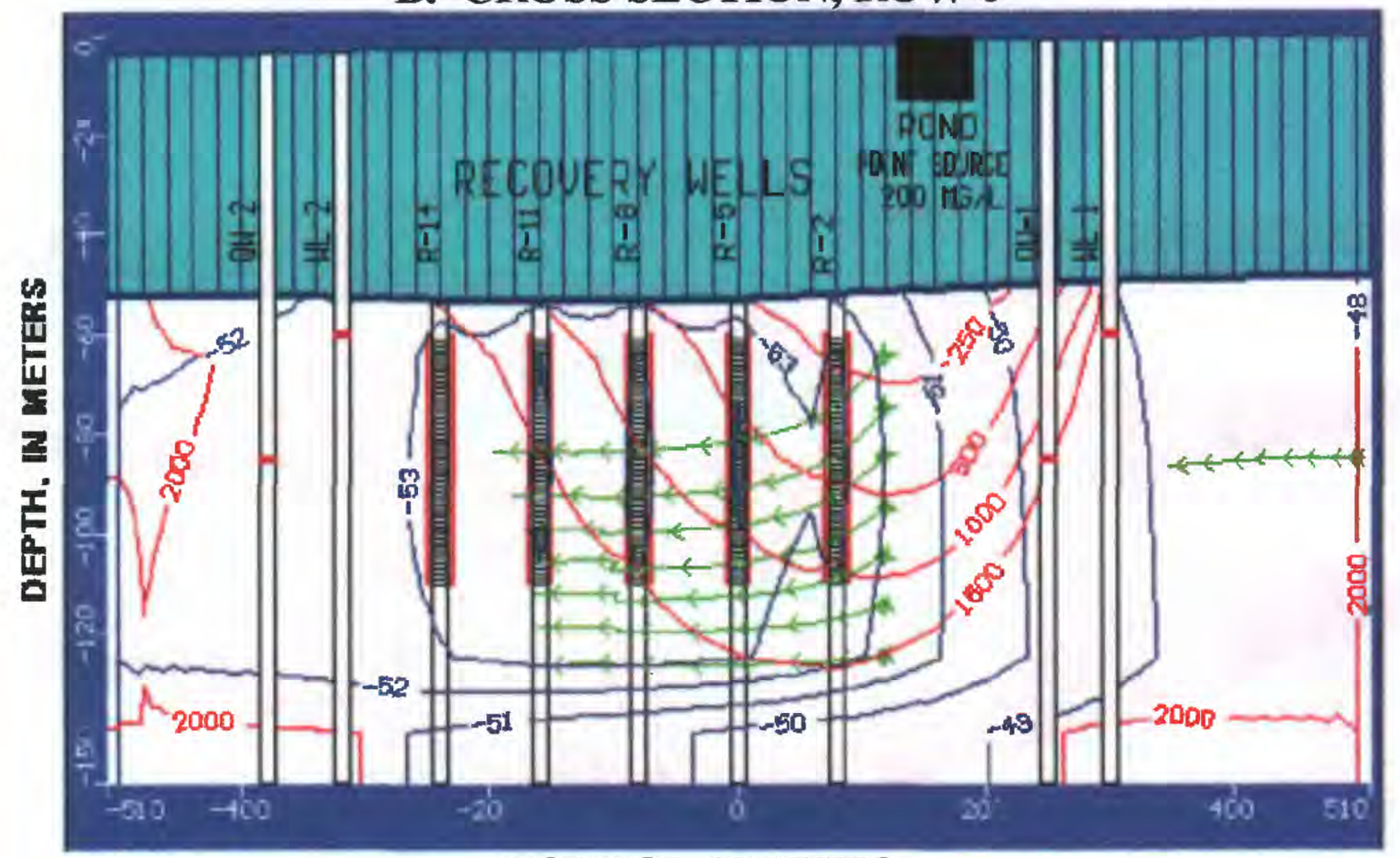

DISTANCE, IN METERS

Figure 19. Simulated heads, dissolved-solids concentrations, and flow pathlines after 1,095 days (3 years) of recharging 1,000 cubic meters per day and 10 days of pumping 15,000 cubic meters per day in the aquifer storage recovery strategic reserve model. 


\section{A. 1,085 DAYS: END OF 3-YEAR POND INFILTRATION PHASE}

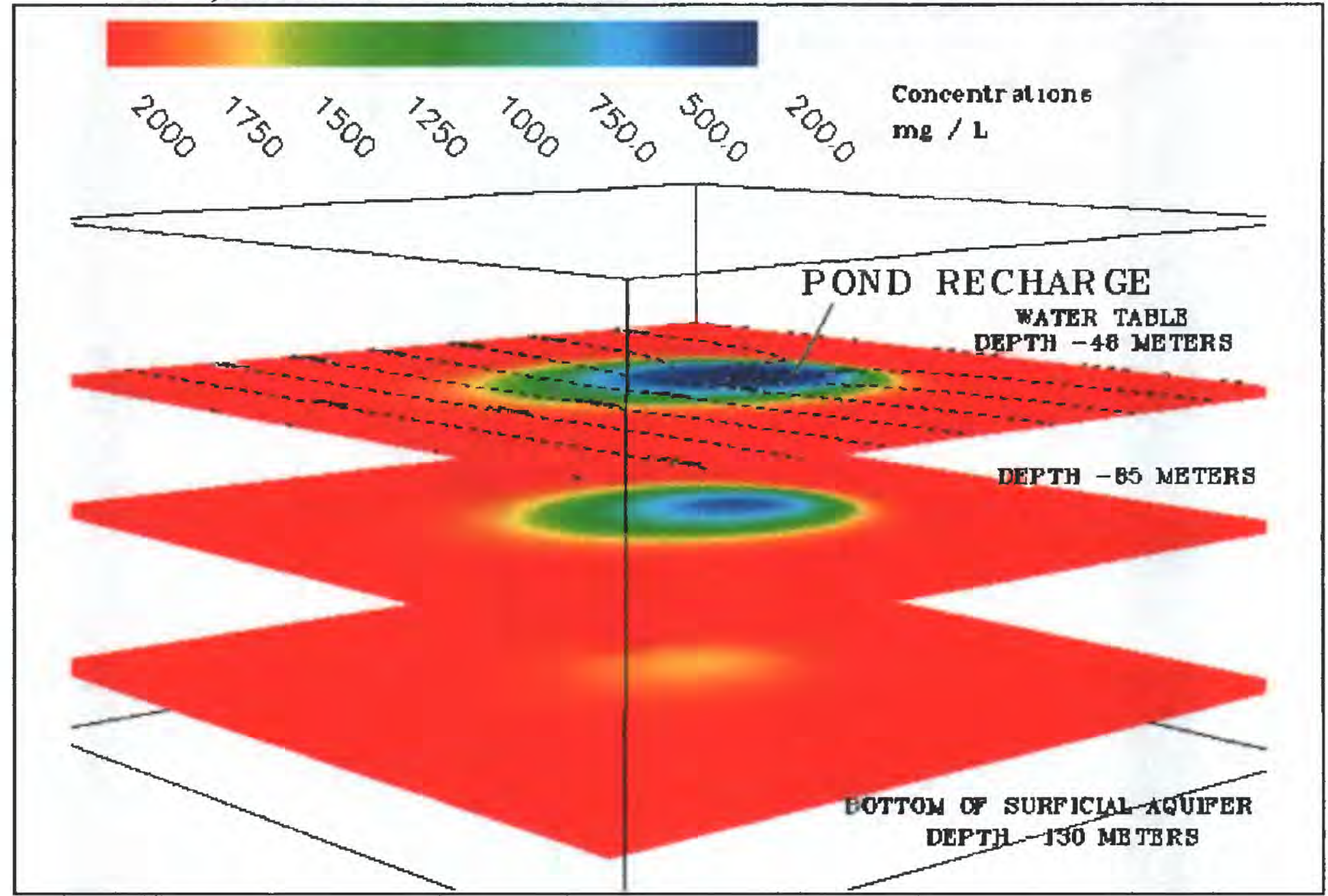

B. 1,095 DAYS: END OF 10-DAY ASR WELL FIELD RECOVERY PHASE

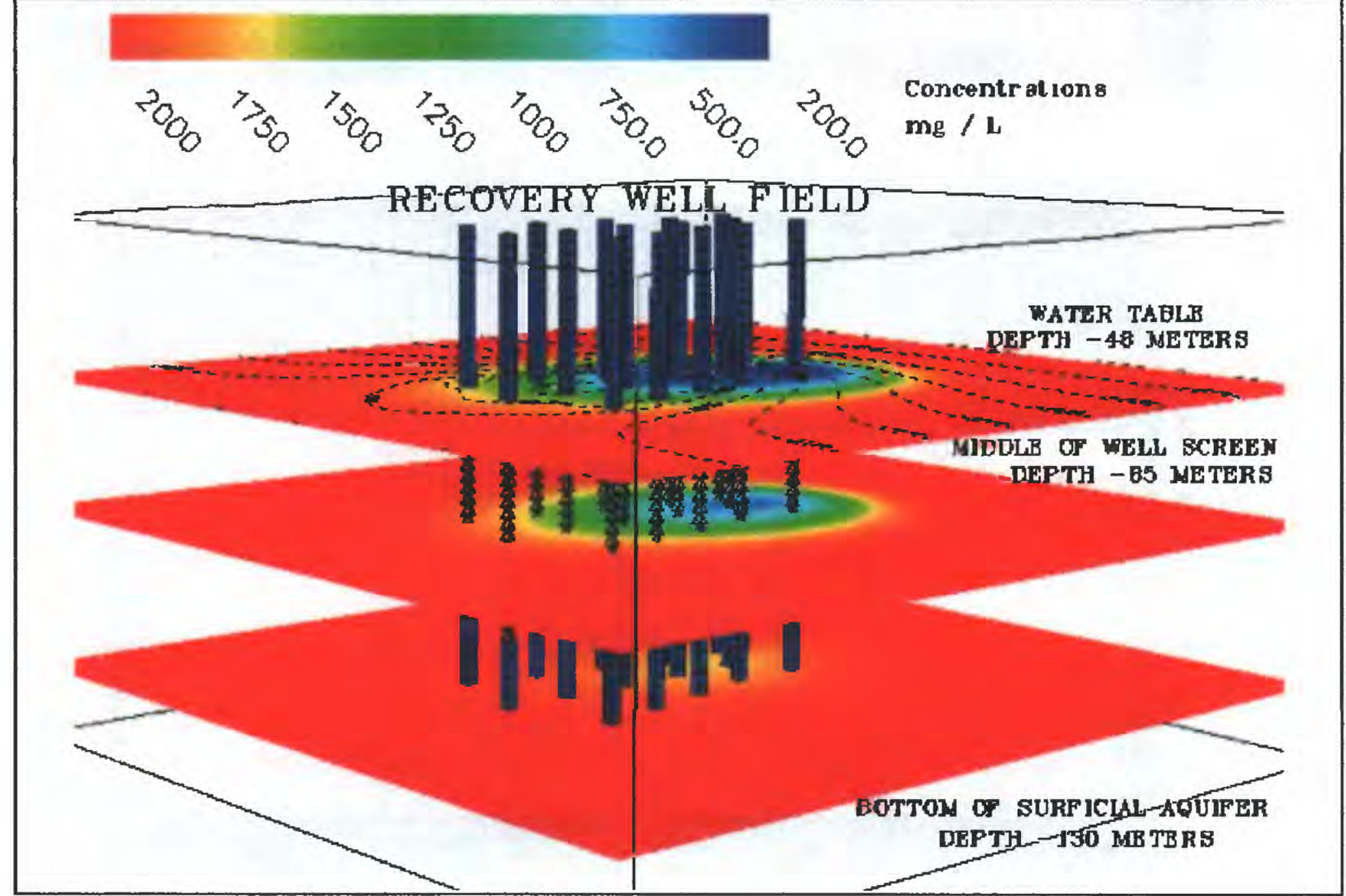

Figure 20. Visualization of the water table and dissolved-solids concentrations in the surficial aquifer system at the end of one cycle of simulated storage (A) and recovery $(B)$ of desalinated water in the strategic reserve model. 


\section{CONCLUSIONS}

Visual Modflow and Visual Groundwater are useful tools for analyzing groundwater systems for impacts of hydraulic stresses and introduced chemical constituents. The analyst should take care not to overinterpret the model results, especially as shown in these example cases, which were developed to demonstrate modeling capabilities. In order to fully evaluate aquifer storage recovery (ASR) alternatives, field tests would be required to obtain site-specific aquifer properties and local water-level gradients. Following this, injection or infiltration tracer tests could be conducted to monitor the spread of the recharged water. With these data in hand, a representative model could be calibrated to simulate the observed conditions. Once the calibration was complete, various parameters could be adjusted within reasonable ranges observed in the field to test the sensitivity of the model and determine needs for further field tests. For example, if the model is sensitive to a 50-percent change in porosity, then it would be prudent to conduct geophysical logging and laboratory tests on core samples to refine the porosity estimate. However, if the plume is controlled more strongly by head gradients, then a refined water-level map would be of value.

Models are worthwhile tools for studying ASR concepts. From the preliminary simulations of average hydrologic conditions, a study area should be at least one square kilometer in size for a small-scale test on the order of 1,000 cubic meters per day. Because ground water moves slowly, tests would need to be conducted over a long period of time, on the order of years rather than days, to observe plume generation and movement. Well construction could be tailored to specific objectives. For example, water-level observation wells could be screened just below the water table to save expense, quality-ofwater observation wells could be screened in the midpoint of the aquifer or near the water table depending on whether wells or a pond are used for the storage phase to ensure measurement of the lowest plume concentrations, and recovery wells could be screened in the upper two thirds of the aquifer to reduce upwelling of formation water. The models demonstrated that ASR can be useful for augmenting the dwindling ground-water resources of Al Ain area.

The surficial aquifer system near $\mathrm{Al}$ Ain was selected for the model simulations for several reasons. The Ground-Water Research Program of the National Drilling Company has constructed hundreds of wells near $\mathrm{Al}$ Ain and has a comprehensive data base that includes well construction, aquifer characteristics, and ground-water quality. The aquifer contains mainly fresh to slightly brackish water, not dissimilar to the desalinated supply. Two desalinization pipelines run through the area, thereby offering many choices for positioning an ASR site.

It might be feasible to construct an ASR facility at a desalinization plant, however, little is known about the hydrology of the coastal ground-water conditions. It is known that the shallow aquifer is fully saturated and contains brine with a total dissolved-solids concentration as much as three times that of seawater. Based on this information, it can be concluded that there is no unsaturated zone above the water table, therefore, storage by pond infiltration is not possible. If a deep confined aquifer is located, buoyancy caused by the density contrast between the native brine and injected freshwater would propagate a fairly thin lens of freshwater that floats on the brine. Experience with situations such as this at sites in the United States has demonstrated that it is feasible to inject the freshwater, however, recovery is impeded by upconing of native brine. 
This report has demonstrated through hypothetical examples that it is feasible to store excess desalinated seawater underground and withdraw it the future. A demonstration project could be conducted with activities including:

- Select an ASR test site along one of the desalinization pipelines, preferably one that can supply water that is excess to other needs for a long-term test.

- Conduct a program of drilling and testing to measure aquifer hydraulic properties, ensure that the aquifer can accept at least 1,000 cubic meters per day, and determine that the native ground water is fresh or slightly brackish (less than $2,000 \mathrm{mg} / \mathrm{L}, \mathrm{TDS}$ ).

- Develop preliminary computer models of ground-water flow and solute transport to simulate and visualize the ground-water system at the selected site under several options for ASR.

- Based on the modeling and knowledge of the site, install an injection well or infiltration pond, water-level and water-quality observation wells, and recovery wells.

- Install electronic water-level and water-quality monitors in the observation wells and water meters on the desalinization pipeline and recovery well discharge line.

- Conduct long-term tests of ASR, preferably for a year or more, using a natural tracer, such as chloride or specific conductance, to define the slug of stored water and monitor how it disperses with distance from the storage point.

- Calibrate the computer models of the ground-water system so that they simulate observed conditions and use them to simulate future ASR management alternatives. 


\section{REFERENCES}

Abdulrazzak, M.J., 1997, Water supply augmentation through artificial groundwater recharge techniques: Water Sciences \& Technology Association Proceedings of the Third Gulf Water Conference, March 8-13, Muscat, Sultanate of Oman, p. 241-281.

Abu Dhabi Water and Electricity Authority, 1997, 1997 operating results of power and desalination stations: Abu Dhabi Water and Electricity Authority Report, [100 p].

Anderson, M.P., and Woessner, W.W., 1992, Applied groundwater modeling; simulation of flow and advective transport: Academic Press, Inc., San Diego, California, 381 p.

Freeze, R.A., and Cherry, J.A., 1979, Groundwater: Prentice Hall, Inc., Englewood Cliffs, New Jersey, 604 p.

Guiguer, Nilson, and Franz, Thomas, 1996, Visual MODFLOW [ver. 2.00]: Consulting engineer's report by Waterloo Hydrogeologic, Waterloo, Ontario, Canada, 196 p.

Hassan, Dahi, 1998, Salvage barge to be scuttled: Gulf News, February 12, 1998, p. 3.

McDonald, M.G., and Harbaugh, A.W., 1988, A modular three-dimensional finitedifference ground-water flow model: U.S. Geological Survey Techniques of Water-Resources Investigations, Book 6, Chapter A1, 586 p.

Pyne, R.D.G., 1994, Groundwater recharge and wells; a guide to aquifer storage recovery: CRC Press, Inc., Boca Raton, Florida, USA, 376 p.

Tamayo, J.M., 1997, Areas where ground-water contamination risk is high, Al Ain area, Abu Dhabi Emirate: National Drilling Company Map Series, 97-001, 1 sheet, scale $1: 125,000$.

United Arab Emirates University, 1993, The national atlas of the United Arab Emirates: United Arab Emirates University, Al Ain, Abu Dhabi, 164 plates.

Waterloo Hydrogeologic, Inc, 1996, Visual groundwater [ver. 2.1] user guide: Consulting engineers' report by Waterloo Hydrogeologic, Inc., Waterloo, Ontario, Canada, $241 \mathrm{p}$.

Zheng, C., 1990, MT3D, A modular three-dimensional transport model for simulation of advection, dispersion, and chemical reaction of contaminants in groundwater systems [ver. 1.1]: Reference Manual by Waterloo Hydrogeologic, Inc., Waterloo, Ontario, Canada, $163 \mathrm{p}$. 


\section{ATTACHMENT 1: APPLICATIONS OF AQUIFER STORAGE RECOVERY IN ARABIAN GULF COUNTRIES}

Experimental tests of ASR have been conducted in the Arabian Gulf countries of Kuwait and Qatar. The anticipated water sources were excess desalinated water, flood water, and imported water. The water was either routed to recharge wells or infiltration ponds to build a strategic reserve to be used during shortages. Brief descriptions of these pilot projects were summarized by Abdulrazzak (1997, p. 266-269) as follows:

\section{Kuwait}

Excess desalinated water produced during the winter season in the past encouraged responsible groundwater authorities in Kuwait to evaluate artificial groundwater schemes. Preliminary hydrogeological investigation indicated that the sandstone formations of Kuwait group at Rawadatain and the limestone Dammam formations at Sulabiya were potential recharge sites. The initial recharge field investigations focused on the Rawadatain site because of the presence of a water supply well field consisting of 121 test holes and observation wells, as well as 26 production wells, completed in 1964 . The Rawadatain aquifer represents the Dibdibba formation consisting of sandstone, conglomerate and siltstone. The first recharge experiment consisted of ten infiltration tests in two recharge pits, and two well injection tests during the period 1961-1964. The objectives of the tests were to examine aquifer behavior in order to evaluate formation capability and potential clogging.

Encouraging results were obtained from pits which showed high infiltration rates, leading subsequently to the construction of other pits in 1964, covering an area $870 \mathrm{ft}$ long, $31 \mathrm{ft}$ wide and $11 \mathrm{ft}$ deep, which achieved 22,000 $\mathrm{m}^{3} /$ day. The source water was runoff collected at Rawadatain which occurred in 1977 and resulted in water level rises of one meter, with travel time of 80-90 hours.

The well injection experiment at Rawadatain continued, and in 1972 two injection tests were carried out, later followed by a 27 day long injection test in 1973. The long test of 1973 provided results on recharge water level rise from 8.2 to $15.2 \mathrm{~m}$, and its decay. Another injection test was made in 1977 to focus on water quality aspects. The outcome of various injection tests favored the implementation of artificial injection-recovery schemes at the Kuwait group aquifers at Rawadatain. The Scheme suggested the use of pits surrounded by and injection recovery well field. A plan was made for the Rawadatain site to implement an artificial recharge project using the existing pits to be surrounded with five to eight wells for injecting a volume ranging from 19,000 to 38,000 $m^{3} /$ day over a four month period.

Further efforts were made in 1990 to investigate the other potential Dammam limestone formation at Sulabiya. Two sites were tested, one at the Dammam confined aquifer, and the other at the overlying Kuwait group, containing brackish water, using three injection wells to evaluate water mixing problems.

Testing procedures included use of sodium fluorescein dye and tritium to assess the mixing between natural and injected water. A single injection-recovery cycle was utilized and there were plugging problems resulting from suspended solids. Test results were not conclusive and suggested limited storage and recovery potential at the Sulabiya site. 


\section{Qatar}

Development activities in Qatar have resulted in mining of the groundwater resources. Qatar has implemented a number of measures to manage its limited water resources. One of these methods is a groundwater recharging scheme where runoff collected in depressions is diverted to a large number of recharging wells that facilitate the transfer of flood water to the underlying Rus and Umm er-Radhuma aquifers. The shallow depressions where runoff is usually collected were formed by subsurface collapse of geological structures as a result of extensive solution and removal of anhydrides and calcium carbonates. These depressions range in size from a few hundred meters up to three kilometers. They are covered by colluvial soils made of calcius, sandy and sandyclay loam.

Artificial groundwater projects using runoff collection depressions and recharge wells in Qatar were initially implemented in 1987 through the use of five recharge wells located in some of the lowland. The system was eventually expanded to include 140 wells. During the period 1977-1988, monitoring of the groundwater level indicated that recharge volume had increased by $30 \%$. Water level fluctuations indicate the response of wells to rainfall-runoff events. Eight hundred new recharge wells were planned for construction beginning in 1994.

Past artificial groundwater activities in Qatar consisted of the use of a large scale flood water recharge well scheme implemented over most of the area of Qatar. More recently, a pilot recharge project has been put into effect involving large depressions where runoff usually collects and is then diverted to numerous recharging wells. The wells recharge the carbonate Rus and Umm er-Radhuma formations. Diminishing groundwater supplies have compelled authorities to evaluate the feasibility of large scale artificial recharge schemes for the building of strategic reserves. The objectives of the feasibility study is to investigate the capability of the water bearing formations to store injected water, and to determine the efficiency of removal for later use. The feasibility study consisted of drilling and testing of boreholes and a program of injection and water recovery test cycles at four sites. The study was implemented on the Rus and Umm er-Radhuma formations located in the northern region of the country, over a two year period from 1992-1994. The program of work consisted of drilling, pump tests, geophysical well logging, water quality monitoring, tracer analysis, many injection recovery cycles, and site modeling of both aquifers. In each site, well configuration consisted of a pumping well and three observation wells, two of which were located perpendicular to the others. An additional two wells were included, one for providing injection water and the other to dispose of water. The four selected sites represented a range of different hydrogeological regimes expected in northern Qatar. A fluorescent dye tracer was used for most of the sites to label the injected water. The results of this large scale artificial recharge study identified the layers in both aquifers as having potential for building up groundwater reserves. A number of artificial recharge scenarios were identified through detailed analysis and interpretation of data, as well as site modeling simulations. The scenarios included options of recharging the aquifers from either desalinated water or imported surface water for the purposes of building strategic reserves, enhancing capacity of existing well fields, water supporting existing farms, and control of saltwater intrusion. In summary, the study identified the best areas for water injection volume and optimum methodology for water injection and recovery. The study can be used as an excellent guideline for countries of the region that are planning to undertake artificial recharge schemes. 


\section{ATTACHMENT 2: DEFINITIONS ${ }^{1}$}

Advection-The movement of a solute at the speed of the average linear velocity of ground water.

Aquifer storage recovery - the storage of water in a suitable aquifer through a well or infiltration pond during times when water is available, and recovery of the water by pumping from wells during times when it is needed.

Confining layer-layer of material that does not readily transmit water because of its low hydraulic conductivity.

Concentration boundary-condition in solute transport modeling where the chemical concentration in a cell or group of cells is held constant.

Constant head boundary - condition in ground-water modeling where the head, or water level, in a cell or group of cells is held constant.

Desalinization, also desalination-removal of salt from water.

Dispersion-Spreading or mixing of a solute caused by the fact that not all the solute actually moves at the same speed as the average linear velocity of the ground water.

Dispersivity-numerical coefficient that supposedly simulates mixing, or dispersion, when a solute is introduced into a ground-water system.

Head equipotential-contour line on a map along which the water level is at the same elevation.

Hydraulic conductivity—measure of the ability of an aquifer to transmit water.

Hydraulic stress-change of inflow or outflow usually represented by pumping or injection at wells.

Porosity-fraction of a unit volume of porous material that is void space.

Specific storage - volume of water released from storage within a unit volume of porous material per unit decline in hydraulic head.

Specific yield-the volume of water that an unconfined aquifer releases from storage per unit surface area of aquifer per unit decline in the water table.

Stress period-condition in ground-water modeling that represents the time when water is being added or removed from the aquifer at a constant rate.

Total dissolved-solids concentration-a laboratory measurement of the salinity of water: less than $1,500 \mathrm{mg} / \mathrm{L}$, freshwater; 1,500 to $15,000 \mathrm{mg} / \mathrm{L}$, brackish water; 15,000 to 32,000 $\mathrm{mg} / \mathrm{L}$, saline water; and greater than $32,000 \mathrm{mg} / \mathrm{L}$, brine.

\footnotetext{
${ }^{1}$ Definitions are mostly in the authors own words or modified from definitions in Anderson and Woessner (1992) or Freeze and Cherry (1979).
} 


\section{محاكاة اختزان واسترجاع فائض تحلية مياه البحر \\ في منطقة العين - إمارة أبوظبي \\ إعداد : كريج · ب . منشنسون \\ الملانحص}

إن المياه الجوفية العذبة والحيويَة الموجودة في الحزانات الحوفية قليلة العمق في منطقة العين في طريفها للنضوب. أنتجت معطات تحلية مياه البحر

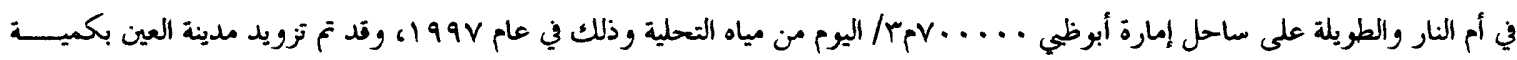

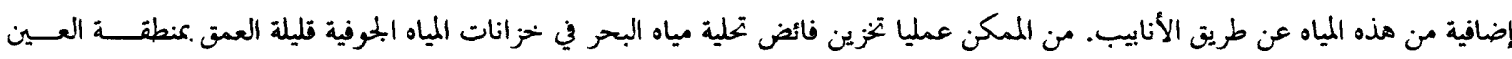

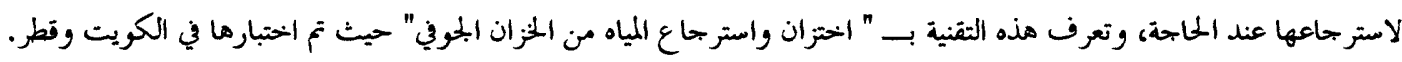

استخدمت برامج النمذجة بالكمبيوتر "Visual Modflow, Visual Groundwater" وذلك لمحاكاة ومشاهدة ثلالة نمساذج مفترضسة

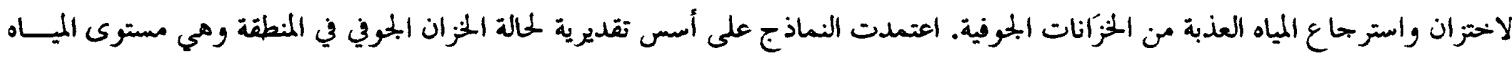

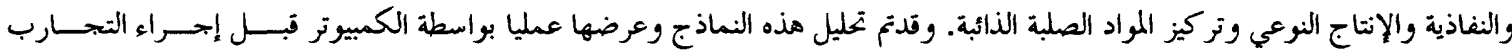
الفعلية في المقل.

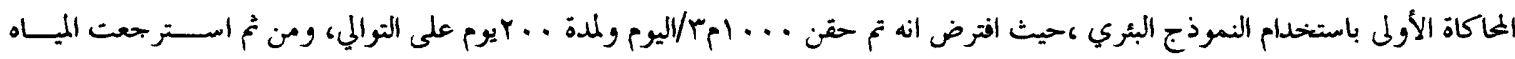

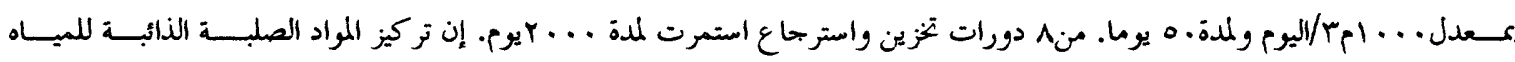

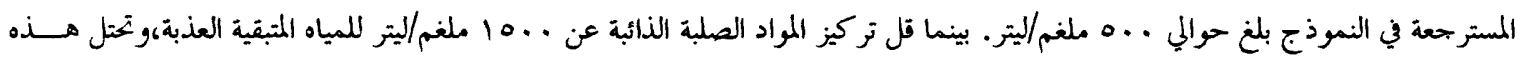

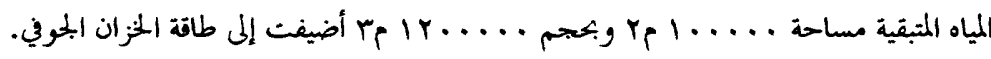

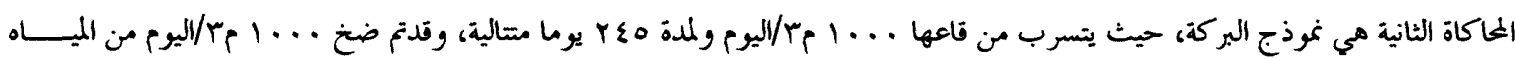

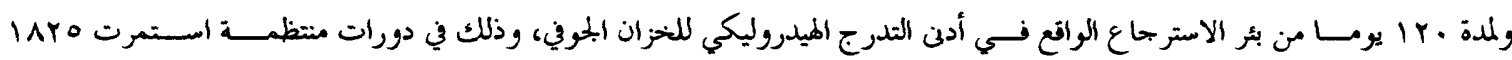

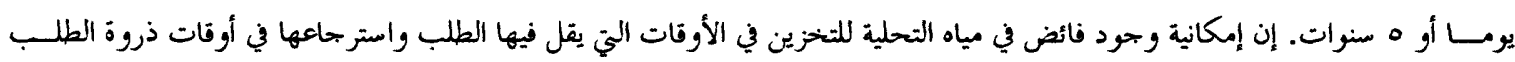

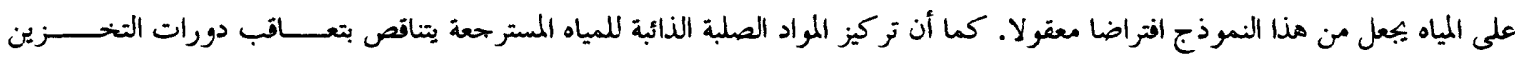

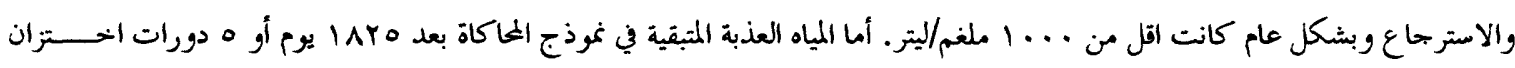

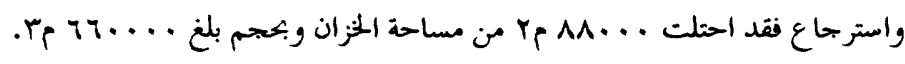

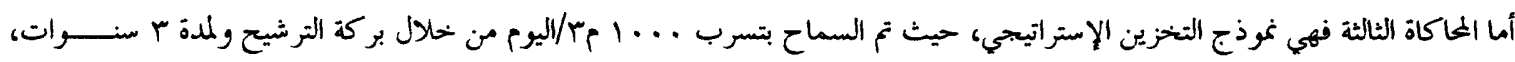

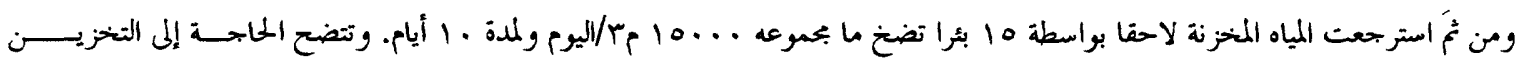

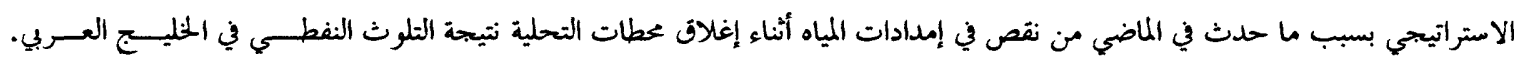

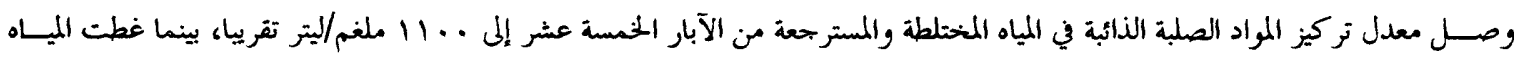

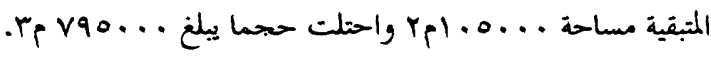

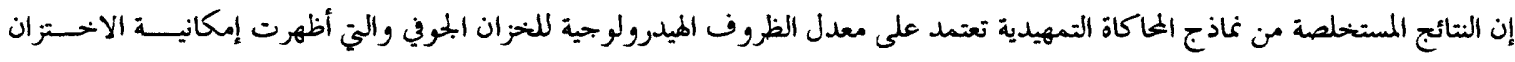

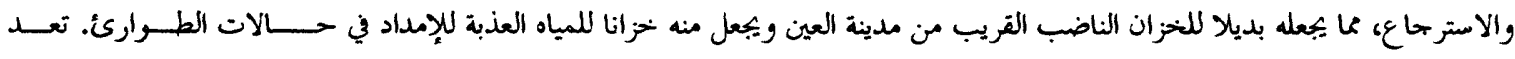

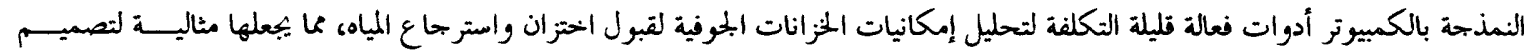

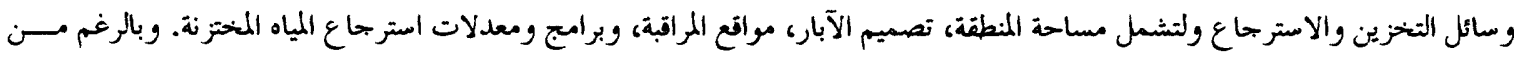

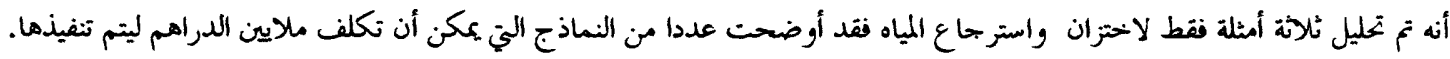

